Portland State University

PDXScholar

2-12-1993

\title{
From the Middle East to the United States: Stressors and Coping Strategies of Members of a Sacred Culture Living in a Secular Culture
}

Angela J. Taha

Portland State University

Follow this and additional works at: https://pdxscholar.library.pdx.edu/open_access_etds

Part of the Speech and Rhetorical Studies Commons

Let us know how access to this document benefits you.

Recommended Citation

Taha, Angela J., "From the Middle East to the United States: Stressors and Coping Strategies of Members of a Sacred Culture Living in a Secular Culture" (1993). Dissertations and Theses. Paper 4756.

https://doi.org/10.15760/etd.6639

This Thesis is brought to you for free and open access. It has been accepted for inclusion in Dissertations and Theses by an authorized administrator of PDXScholar. Please contact us if we can make this document more accessible: pdxscholar@pdx.edu. 
AN ABSTRACT OF THE THESIS OF Angela J. Taha for the Master of Science in Speech Communication presented February 12 , 1993.

Title: From the Middle East to the United states:

Stressors and Coping strategies of Members of a

sacred culture Living in a secular culture.

APPROVED BY THE MEMBERS OF THE THESIS COMMITTEE:
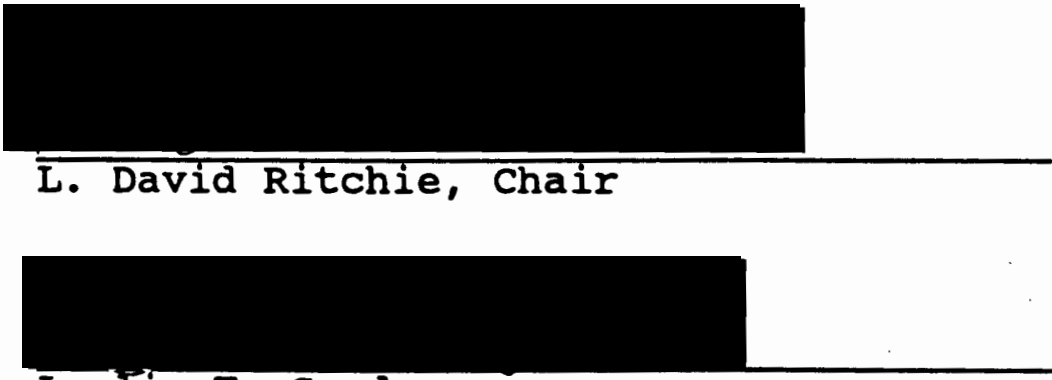

LesIie T. Good

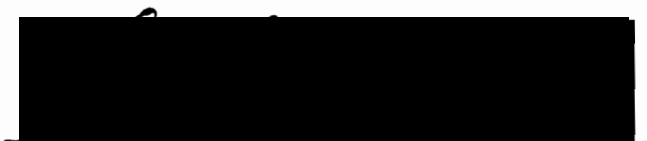

Larry A. Steward

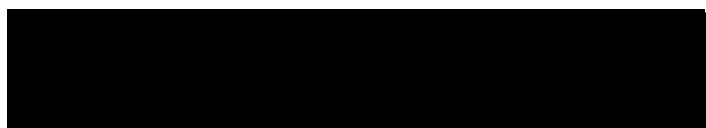

Kimberly A. Brown

The values and beliefs involved in Islam maintain th:c religion is embedded in everyday life. Students from countries which subscribe to the tenets of Islam may have a difficult time adjusting to the secular society of the U.. $\mathrm{S}$. 
This study is concerned with the interrelationships among events perceived as stressful, the ways of coping with stress that are reported as most often used, and the reported level of satisfaction with living in the U.S. for the Muslim Arab international students in this study.

A four page survey questionnaire was used as the instrument. The questionnaire was filled out by 102 Muslim Arab international students regarding the areas of stressors, coping strategies, satisfaction with living in the U.S., and individual descriptors. None of the hypotheses were supported with statistically significant results. Of the subjects, $83 \%$ reported that they did not receive any intercultural pre-sojourn training. Presently, pre-sojourn intercultural training does not aid in reducing the stressful situations experienced by these subjects (Hypothesis 1). The frequency of emotion-focused coping does not decrease when the perceived effectiveness of presojourn intercultural training increases (Hypothesis 2). Limited knowledge and standardized research in this area may contribute to the lack of success of intercultural training. Additional time spent living in the U.S. does not reduce the communication-related stressors Muslim Arab students experience (Hypothesis 3). Although research indicates the longer people live in a foreign culture, the more they learn the rules and norms and therefore become acculturated (Samovar and Porter, 1988), the additional considerations a 
Muslim Arab international student may have to deal with could override the positive effects of time. The frequency of emotion-focused coping does not substantially decrease the longer amount of time a student has lived in the U.S. (Hypothesis 4).

stress is a part of any student's life. For Muslim Arab international students living in the U.S., the basic value system provided by the belief in Islam appears to be related to coping with stressful situations (Hypothesis 5). However, the results were not significant.

As the variety of coping strategies increases, the variety of stressors does not decrease (Hypothesis 6). Rather, as the variety of stressors increases, so too does the variety of coping strategies. It appears that students who experience more stressors respond by using more coping strategies.

Satisfaction was correlated with neither coping strategies nor stressors. One would expect satisfaction to be positively related to coping strategies (Hypothesis 7), but there was no relationship. One would also expect satisfaction to be inversely related to stressors (Hypothesis 8 ), but there is no relationship. Satisfaction was measured by the extent to which subjects would want to remain in the U.S., and if they would recommend a loved one to study in the U.S. Based on the highly obligatory social structure that exists in many Middle Eastern countries, 
contemplating remaining away from one's family and friends may not have been acceptable. Difficulties associated with living in the U.S. as an international student may have also led subjects to report they would not recommend a loved one to study in the U.S.

In conclusion, there are three important results that can be drawn from this study. First, with respect, at least, to the Muslim Arab international students in this study, there is no way to empirically discriminate between different categories of stressors or different categories of coping strategies. Second, denial and wishful thinking are not effective coping strategies. Third, direct problem solving is clearly the most effective way for the Muslim Arab international students in this study to cope with stressors while living in the U.S. 
FROM THE MIDDLE EAST TO THE UNITED STATES:

STRESSORS AND COPING STRATEGIES OF MEMBERS

OF A SACRED CULTURE LIVING IN A SECULAR CULTURE

by

ANGELA TAHA
A thesis submitted in partial fulfillment of the requirements for the degree of
MASTER OF SCIENCE
SPEECH COMMUNICATION

Portland State University

1993 


\section{DEDICATION}

To the memory of my sister, Pamela Rose Difabio Crain, a free and creative spirit. 
TO THE OFFICE OF GRADUATE STUDIES:

The members of the Committee approve the thesis of Angela J. Taha presented February 12, 1993.

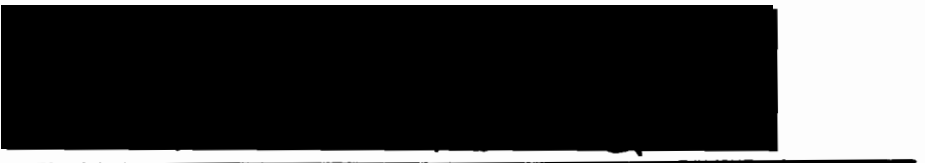

L. David Ritchie, Chair

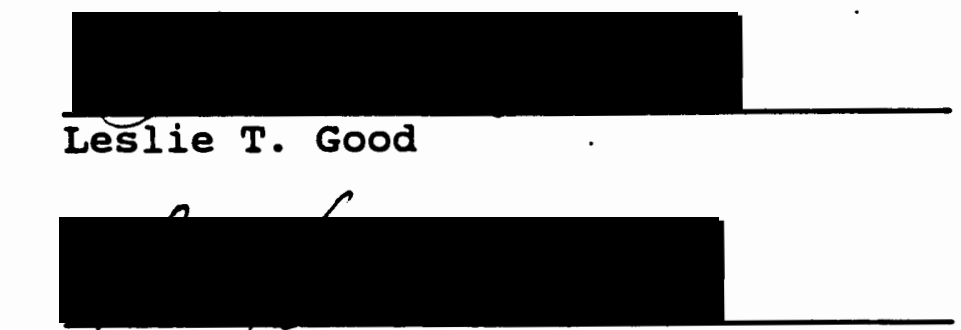

I.arry A'. Steward

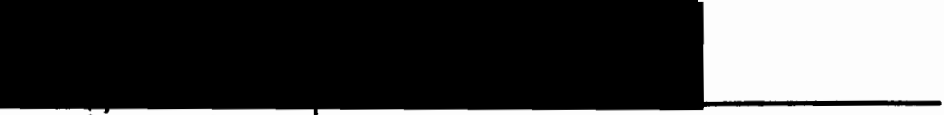

Kimberly A Brown

APPROVED:

Stepher Kosokoff, Chair, Department of Speech Communication Roy Kochi, Interim Vice Provost

Roy Koch, Interim Vice Provost for Graduate studies and Research 


\section{ACKNOWLEDGEMENTS}

I cannot begin to express the gratitude and respect I have for you, Dr. Ritchie. The patience you exhibited during long grueling meetings, your responses you sent to the frantic notes I sent over e-mail, and your ever-present sense of humor encouraged me to continue when quitting looked so appealing. I can finally say it: NOW I am having fun.

Dr. Good, Dr. Steward, and Dr. Brown: Your editing skills and avid curiosity have always kept me thinking. A special thanks for your diligence and thoroughness that has made this a stronger piece of research. Dorothy Sermol and Devorah Lieberman: You both played special roles in my understanding and appreciation of intercultural communication.

To my husband Ali, I could not have made it one single day without you by my side. Thank you for your insights and thoughtfulness. Bonnie Bray, Theresa Lunsford, Laura Perry, and Angela Waine: I don't know how you did it, but you have always said the words that made this all seem possible.

Mom and Dad, my greatest thanks go to you. I would not be the person I am today without your unconditional love and support. I began college to gain your respect, and in turn, gained self-respect. What a treasure you have led me to 
find.

To all of my family and friends: Thank you and I love you. 
TABLE OF CONTENTS

PAGE

ACKNOWLEDGEMENTS . . . . . . . . . . . . . . . iii TABLE OF CONTENTS . . . . . . . . . . . . . . . v LIST OF TABLES . . . . . . . . . . . . . . . . vii CHAPTER

I INTRODUCTION . . . . . . . . . . . . . 1 Rationale . . . . . . . . . 5 Significance . . . . . . . . . . . 7

II THEORETICAL FOUNDATION. . . . . . . . . 8 Cultural Interpretation . . . . . . 8 Arabism and Arab Values. . . . . . . . 9 Cultural Background. . . . . . . . . 14 Stress and Stressors . . . . . . . . 22 Coping Strategies. . . . . . . . .26 Hypotheses . . . . . . . . . . . . 28

III METHOD . . . . . . . . . . . . . . . .32

Purpose of study . . . . . . . . . . 32

Subjects . . . . . . . . . . . . 32

Instrument . . . . . . . . . . . .33

Definition of Variables. . . . . . . .34 Analysis . . . . . . . . . . .38 


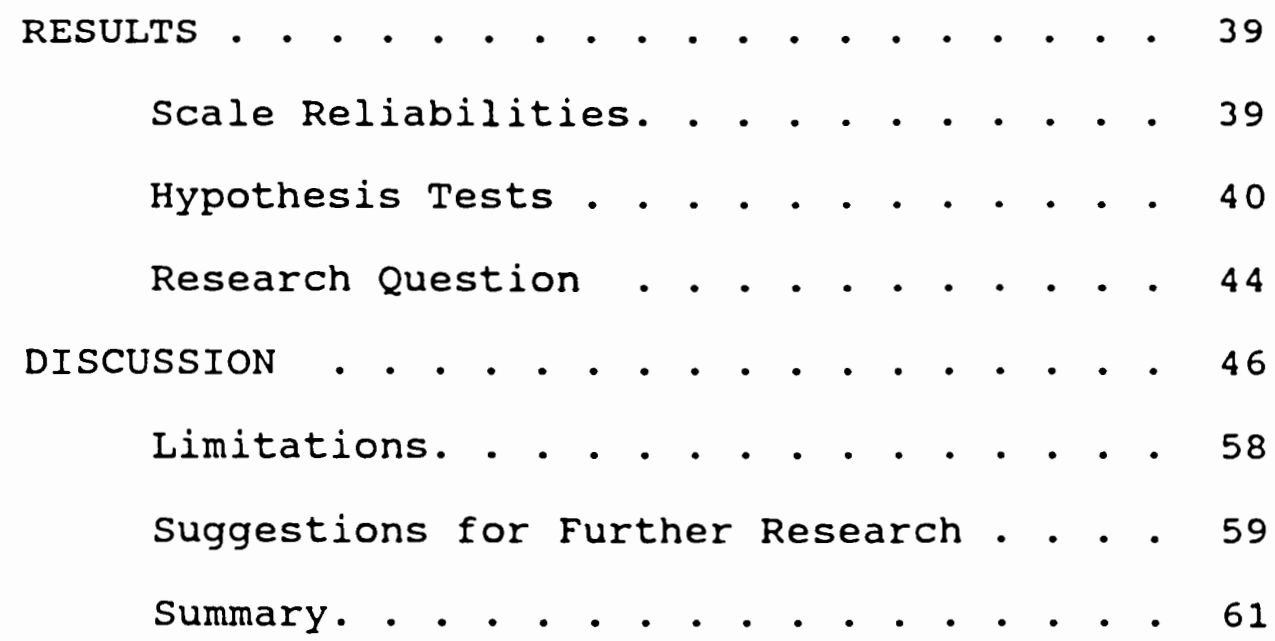

A VARIAble CAtEgories AND RELIABILIties . • • 69

B QUESTIONNAIRE • • • . . . . . . . . . . 73

C PILLARS OF ISLAMIC FAITH . . . . . . . . 80 


\section{LIST OF TABLES}

TABLE

PAGE

I Individual Descriptor Frequencies . . . . . . 4

II Satisfaction Indicators . . . . . . . . . 45 
CHAPTER I

\section{INTRODUCTION}

For thousands of years, students have been traveling abroad to receive an education. More than ever, in fact, students are traveling from a variety of different countries to receive an education in the U.S. (Furnham \& Bochner, 1982). Some students travel under the auspices of programs, such as American Field Service (AFS) or the Rotary International, that help support them financially and emotionally by providing them with home stays or host families. However, many students from the Middle East travel independently or on government scholarships. These government scholarships provide the financial support students need while studying abroad. In exchange, students agree to work in a designated company after graduation. Pre-sojourn intercultural training (see Adler, 1977; Brislin, Cushner, Cherrie, \& Yong, 1986; Paige, 1986) may be provided for the students going overseas, yet on arrival students may receive limited training or support for their adjustment (Dawn White-Personal communication 03-31-92). As a result of my marriage to a Muslim Arab international student, I have had many opportunities to observe both the stresses associated with a sojourn in the U.S. and the 
various ways in which Muslim Arab international students cope with these stresses. This has led me to wonder how the students' repertoire of coping strategies are related to the success of their sojourn here.

As international students come to the U.S., they may experience daily activities that accentuate differences between the cultures of their own countries and the dominant U.S. culture. These differences may range from how North Americans use a fork, to how they rent an apartment or open a checking account. Even if international students accomplish daily tasks, cultural differences may be psychologically stressful to them.

An international student's adjustment to university life may be complicated by the lack of primary family relationships or support systems (Fontaine, 1986). People from the Middle East rely primarily and almost exclusively on the family for emotional and monetary support (Nydell, 1987). Without the support of the family, these students often have to learn through their own experiences how to cope with the stress related to being a Muslim Arab international student in a university in the U.S.

During January of 1991, the U.S. and its allies engaged in a war with Iraq. Destruction in the Middle East was widespread, not limited to Iraq alone. Students with Arab ethnic roots found this war particularly stressful. "In Dearborn, many Arab-American students said. . that the 
war was deeply distracting and saddening" (Heller, 1991, p. A1). Not only did they have to worry about the future of their countries, but they were students in one of the countries that was fighting in the Middle East. An Arab student said, "I can't sit in classes and take notes. A part of me is being threatened and being destroyed, whether it be Iraqi people or American soldiers" (Heller, 1991, p. A29)

In addition to reconciling their feelings about the recent war, many Arab students who come to study in the U.S. are Muslim and are accustomed to abiding by the specific moral code of Islam. This is important to note because in order to provide as much specificity as possible, and still have a sample large enough to be valid, people who are international students, Muslim and Arab were used in this study (See Table 1).

Belief in the Islamic faith provides a guideline for everyday living. "Islam is more than a religion; it is the totality of culture in both its social and individual aspects. It is a way of life" (Almaney \& Alwan, 1982, p. 43). When Muslim Arabs come to the U.S. they encounter a culture where religion is not necessarily embedded in everyday activities. "The United States generally is regarded as a secular society. Religion plays a less significant role in contexting communication behavior than the other subsystems of society" (Johnson \& Tuttle, 1989, 
TABLE I

INDIVIDUAL DESCRIPTOR FREQUENCIES

\begin{tabular}{|c|c|c|}
\hline Individual Descriptor & Frequency & Percentage \\
\hline $\begin{aligned} & \text { SEX: } \\
& 1 . \text { male } \\
& 2 . \text { female } \\
&\end{aligned}$ & $\begin{array}{l}1.90 \\
2 . \quad 12 \\
\end{array}$ & $\begin{array}{l}1.88 \% \\
2 . \quad 12 \% \\
\end{array}$ \\
\hline $\begin{array}{l}\text { NATIVE CounTRY: } \\
\text { 1: Lebanon } \\
\text { 2: Syria } \\
\text { 3: Palestine } \\
\text { 4: Oman } \\
\text { 5: U-A-E } \\
\text { 6: Saudi Arabia } \\
\text { 7: Kuwait } \\
\text { 8: Iraq } \\
\text { 9: Yemen } \\
\text { 10: Jordan } \\
\text { 11: Egypt } \\
\text { 12: Somalia } \\
\text { 13: Bahrain } \\
\text { 14: Qatar } \\
\text { 15: Sudan } \\
16: \text { Libya } \\
\text { 17: Morocco } \\
\text { 18: Tunisia } \\
\text { 19: Algeria } \\
\text { 20: South Yemen } \\
\end{array}$ & $\begin{array}{l}1: 21 \\
2: 9 \\
3: 17 \\
4: 6 \\
5: 8 \\
6: 16 \\
7: 6 \\
8: 2 \\
9: 8 \\
10: 5 \\
11: 0 \\
12: 2 \\
13: 2 \\
14: 0 \\
15: 0 \\
16: 0 \\
17: 0 \\
18: 0 \\
19: 0 \\
20: 0\end{array}$ & $\begin{array}{l}1.21 \% \\
2: 9 \% \\
3: 17 \% \\
4: 6 \% \\
5: 8 \% \\
6: 16 \% \\
7: 6 \% \\
8: 2 \% \\
9: 8 \% \\
10: 5 \% \\
11: 0 \% \\
12: 2 \% \\
13: 2 \% \\
14: 00 \% \\
15: 00 \% \\
16: 0 \% \\
17: 0 \% \\
18: 00 \% \\
19: 00 \% \\
20: 0 \%\end{array}$ \\
\hline \begin{tabular}{|c|} 
ACADEMIC LEVEL: \\
1. freshman \\
$2:$ Sophomore \\
$3:$ junior \\
4: Senior \\
5: graduate \\
\end{tabular} & $\begin{array}{ll}1: & 12 \\
2: & 13 \\
3: & 20 \\
4: & 31 \\
5: & 25 \\
\end{array}$ & $\begin{array}{l}1 \cdot 12 \% \\
2: 13 \% \\
3: 220 \% \\
4: 30 \% \\
5: 25 \\
\end{array}$ \\
\hline $\begin{array}{l}\text { AMOUNT OF TIME LIVED IN } \\
\text { THE U.S.: } \\
1 . \text { less than } 6 \text { mos. } \\
2: 5 \text { mos to } 1 \text { yr. } \\
3: \text { 1 to } 3 \text { yrs. } \\
4: 5 \text { to } 5 \text { yrs. } \\
5.5 \text { or more yrs. }\end{array}$ & $\begin{array}{ll}1: & 8 \\
2: & 6 \\
3: & 13 \\
4: & 28 \\
5: & 47\end{array}$ & $\begin{array}{ll}1 . & 8 \% \\
2: & 6 \% \\
3: & 13 \% \\
4.5 & 28 \% \\
5 . & 46 \% \\
\end{array}$ \\
\hline $\begin{array}{l}\text { RECEIVED IC TRAINING: } \\
\frac{1}{2} \text {. yo } \\
\end{array}$ & $\begin{array}{l}1.85 \\
2 . \quad 17 \\
\end{array}$ & $\begin{array}{l}1.83 \% \\
2 . \quad 17 \% \\
\end{array}$ \\
\hline \begin{tabular}{|l} 
LEVEL OF EFFECTIVENESS \\
FOR IC TRAINING: \\
1. doesn't apply \\
$2:$ not at ali \\
$3 \cdot$ somewhat \\
4. very \\
\end{tabular} & $\begin{array}{l}1: 72 \\
2: 3 \\
3: 1^{3} \\
4: 4 \\
\end{array}$ & $\begin{array}{ll}1.71 \% \\
2: 3 \% \\
3: 53 \% \\
4: 4 \% \\
\end{array}$ \\
\hline \begin{tabular}{|l} 
TYPE OF EXCHANGE \\
PROGRAM : \\
$1 \cdot$ no program \\
$2 \cdot$ government \\
scholarship
\end{tabular} & $\begin{array}{ll}1 \cdot 65 \\
2 \cdot \quad 19\end{array}$ & $\begin{array}{l}1.64 \% \\
2: 19 \%\end{array}$ \\
\hline $\begin{array}{l}\text { 3. unive exchange } \\
\text { 4. other }\end{array}$ & $\begin{array}{ll}3 \cdot 0 \\
4 . & 16 \\
\end{array}$ & $\begin{array}{ll}3 . & 0 \% \\
4 . & 16 \% \\
\end{array}$ \\
\hline \begin{tabular}{|l} 
ACTIVELY PRACTICE \\
RITUALS OF ISLAM: \\
1. not at all \\
2. somewhat \\
3. completely
\end{tabular} & $\begin{array}{l}1 \cdot 19 \\
2: 50 \\
3: 33 \\
\end{array}$ & $\begin{array}{l}1.19 \% \\
2 \cdot \quad 49 \% \\
3 . \quad 32 \% \\
\end{array}$ \\
\hline
\end{tabular}


p.465). This separation between everyday life and religion affects the experiences of students who adhere to the assumptions of Islam. "In these societies, the teachings of Muhammad determine many aspects of social interaction, including at which time and under which circumstances people may communicate, nonverbal communication, greeting and leave-taking rituals, and how one communicates with strangers" (Johnson \& Tuttle, 1989, p. 465). All of the factors I have mentioned above interested me in how these students cope with the stressors involved in being Muslim Arab students in the U.S.

\section{RATIONALE}

There is not a great deal of empirical research which focuses solely on causal variables of stress for international students. There is an abundance of literature in some of the individual areas of concern such as different types of stress and research about culture shock and acculturation. However, very little has been researched regarding possible links between cultural background, causes of stress, coping strategies, satisfaction outcomes, and individual descriptors. There are three exceptions to this. Dinges, Lieberman, and Tran's 1989 culture-general research based on surveys completed by international students from 33 countries suggested a relationship between international students' stressors and coping strategies, or how they cope 
with stressful events, and their perceived academic self-efficacy. Two theses using an identical instrument supported culture-specific conclusions and the need for further research based on international student subgroups. Both theses, Atzuko Kurogi's (1990) research on Japanese international students and Qiu Lu Liang's (1990) research on Chinese international students, identified unique relationships between culture-specific stressors and coping strategies which are mediated by perceived academic self-efficacy.

Both theses asserted possible relationships between value orientations and stressors. They also asserted relationships between value orientations and coping strategies. However, value orientations were not measured, and all relationships were implied rather than empirically verified. In the present study, value orientations will be measured according to how actively subjects practice the rituals of Islam.

This study will provide new information about Muslim Arab international student adjustment. The knowledge will be made available to anyone interested in Muslim Arab international students through the International student Services (ISS) at Portland state University. The results of this study may be particularly helpful to those Muslim Arab international students who are experiencing a great deal of stress. The information may also offer some solutions to 
problems they may not have thought of themselves. Furthermore, this information is important because Muslim Arabs often do not readily accept the idea of counseling, relying instead on the family. Because many international students do not have family members here, this information may help them deal with the separation from their primary support group. Thus, by using the following information, students who may be feeling stress will have more information at their disposal.

\section{SIGNIFICANCE}

The patterns which this research identifies should provide useful information to Muslim Arab sojourners prior to arrival. For example, the Muslim Arab international students in this study reported that speaking English is not highly stressful. This information may reduce the stress level in one area of concern for students who have not left their native countries. This research is useful because it may provide information to help some Muslim Arab international students adjust to living in the United States. This study asks the question: What are the interrelationships among events reported as frequently stressful, the ways of coping with stress that are reported as most often used, and the reported level of satisfaction with living in the U.S. for the Muslim Arab international students in this study? 


\section{CHAPTER II}

\section{THEORETICAL FOUNDATION}

Situations that may cause stress, and effective ways to cope with stress, influence the level of satisfaction international students have with living in a foreign country. These issues are particularly relevant for international students who come from countries in which their values are embedded in a religious code that guides how they approach daily activities.

\section{CULTURAL INTERPRETATION}

Culture is a way of life developed by a society of people in a particular environment. Culture is a catch word to refer to cultural expectations and interpretations. We, as humans, are all enculturated into the society in which we are socialized. Few of us are aware of this process. Enculturation includes how we are socialized to think, feel, believe and behave within the reality we share with the other members of our culture (Kim, 1988). Culture permeates every aspect of living in any society. This broad idea has been explicitly defined in a variety of ways. According to Samovar and Porter (1988) "culture is the deposit of knowledge, experiences, beliefs, values, attitudes, 
meanings, hierarchies, religion, timing, roles, spatial relations, concepts of the universe, and material objects and possessions acquired by a large group of people in the course of generations" (p. 19).

Culture greatly influences the process of communication. Condon and Yousef (1975) have said culture and communication are inseparable. "We cannot separate culture from communication, for as soon as we start to talk about one we are almost inevitably talking about the other, too" (Condon \& Yousef, 1975, p. 34). Fundamentally, culture is the way members of a society make sense of and interact with the world.

Each culture develops a distinctive perceptual framework for a specific group of people, and intercultural communication takes place when two people from different cultural backgrounds interact with one another. Miscommunication and misunderstandings abound in intercultural interactions largely due to differing culturally conditioned perceptions of reality (Hoopes, 1979). Problems arise because of language barriers, or in the case of a common language, when different connotations are attached to common symbols or symbolic expressions.

\section{ARABISM AND ARAB VALUES}

According to the literature, the term Arab is more descriptive of regional locale, language use, and 
identification with certain cultural and religious characteristics rather than a particular nationality (Almaney \& Alwan, 1982; Musallam, 1983). Although it is true there are many complex cultures in Arab nation-states, "All Arabs share basic beliefs and values which cross national or social class boundaries. Social attitudes have remained relatively constant because Arab society is conservative and demands conformity from its members" (Nydell, 1987, p. 16). The term Muslim Arab may not be a sociopolitical identity, but it does describe a religious and linguistic identity. "Although there are many differences among Arab countries, the Arabs are a clearlydefined cultural group, members of the 'Arab-nation' (alumma al-'arabiyya)" (Nydell, 1987, p. 18). Modern Arab nation-states include Egypt, Saudi Arabia, Jordan, Lebanon, Iraq, Syria, Yemen, South Yemen, United Arab Emirates, Kuwait, Bahrain, Qatar, Oman, Sudan, Libya, Morocco, Tunisia, Somalia, and Algeria.

For the purposes of this study, it is important to understand some fundamental tenets of Islam. "Islam plays a central role in the life of the Arabs" (Almaney \& Alwan, 1982, p. 35). When a situation occurs which requires an ethical judgement or moral consideration, Muslim Arabs often rely upon the values that are emphasized in Islam. "The Muslim milieu is a reservoir formed through thirteen centuries of rich and varied development from which the 
Muslim Arabs continue to draw attitudes, feelings, and assumptions about themselves and about other peoples" (Almaney \& Alwan, 1982, p. 35).

The system that Muhammed established did not recognize separate spheres for "church" and "state." Rather, the two are so meshed together in classical Islam that it is impossible to talk about one in isolation from the other. The Islamic community created by Muhammed was at once a religious brotherhood, a political association, and a social order (Almaney \& Alwan, 1982, p. 43).

The term Muslim Arab in the context of this study does not assume that Pan-Islam plays a unifying role in the politics of Islamic nations. It has been noted by many authors (Lapidus, 1988; Landau, 1990) that a separation between the politics of the nation-states and the politics of Pan-Islam still exists. Landau (1990) cites numerous authors who argue that Pan-Islam and Pan-Arabism are not mutually exclusive. However, to assert political unity among Arab nation-states is not the intent nor desire of this study. Rather, in the context of this study, Muslim Arab refers to the cultural identity manifested through the identity with language (Arabic) and religious belief (Islam). The role of Islam permeates people's nation-state identity even in countries that have attempted to secularize political structure (Lapidus, 1988). "Despite a century-old commitment to secular forms of Arab nationalism, Islam remains an integral part of Arab identity" (Lapidus, 1988, p. 667). The important distinction is between political structures and cultural identity. 
Muslims regard the Qur'an as their sacred book. Within this book, certain stories exemplify the ways Muslims are to behave (Almaney \& Alwan, 1982; Lapidus, 1988). The Qur'an is unique when compared to other semitic texts because it uses humans in stories to exemplify moral behavior rather than allegorical figures or metaphors. The use of humans in the stories may have influenced the value of relational harmony in Muslim Arab culture.

In the Qur'an symbols are subordinated to people, and the myths of the Qur'an involve people whose legendary exploits are disclosed to us by commentators on the text. No non-Muslim can pass judgement on the value of Qur'anic 'myth.' His view will inevitably be subjective and conditioned by the 'mythology' of his own cultural background (Cavendish, 1984, p. 112).

Muhammed "introduce[d] changes in his socity so fundamental that their effects still govern the minds and behaviors of millions of Muslims throughout the world" (Almaney \& Alwan, 1982, p. 43). Islam provides answers to all aspects of life, not just religion. "An Arab's religion affects his whole way of life on a daily basis" (Nydell, 1987, p. 87). Because of its strength and appeal, Islam still functions in much the same way it did during the golden age of Islam (Almaney \& Alwan, 1982). Muslims still believe that power should be used to promote Allah, rather than themselves; time is relative, when we will be judged for eternity on Judgement Day; only Allah can understand His Plan for humanity; patience is necessary for enlightenment; interdependence, respect and hospitality reflect the worth 
of human life; adultery is wrong because it is an unclean and evil act. Perhaps the paramount message about Islam, though, is that through the earthly practice of the five (or six) pillars of Faith, one can reach spiritual harmony with Allah.

Muslims of today accept the first five pillars and the Qur'an as sacred. There is no room for doubt or speculation, and everything is written to be clear to the believer. One reason for the devotion to Islam may be because of the moral guidelines the Qur'an has to offer, and the approach it takes regarding human communication. The ultimate fate of every living being is in the hands of Allah. The Muslims have a saying, Inshaa Allah, which means Allah's will be done; everything that is happening is in accordance with Allah's Plan. Islam, therefore, offers its believers a guide, albeit deterministic, toward spiritual unity with Allah.

Certain values, those things which are considered to be good, are embedded within the doctrine of Islam. Kluckholn and Strodtbeck (1961) developed a model of value orientations which is helpful in looking at examples of different value systems. These value orientations reflect some of the dominant values held by people who belong to specific cultures. The term dominant values, is used here to mean the limited amount of solutions to universal problems and conditions that all humankind must face (Condon 
\& Yousef, 1975). Kluckholn and Strodtbeck's original research contained five categories of value orientations. However, Condon and yousef (1975) expanded upon the five value orientations developed by kluckholn and strodtbeck to make a total of 25 value orientations. Condon and yousef's model of 25 value orientations allows for addressing more specific possibilities. The value orientations that are particularly important to this thesis pertain to the categories of self, family, society, and the supernatural. Values are not held in isolation or distinctly separate from other values. The values that are addressed will be those which are the dominant value represented in a given situation or example.

\section{CULTURAL BACKGROUND}

Values are important factors when considering differences between Muslim Arabs and individuals from the U.S. Many of these differences are expressed in communication styles common to U.S. culture and Muslim Arab culture. Perhaps one of the main differences between cultural communication styles is the concept of high and low context (Hall, 1976). Context refers to the way in which messages are transmitted. Hall (1976) wrote "in real life the code, the context, and the meaning can only be seen as different aspects of a single event" (p. 90). Cultures are neither completely high nor low context, but tend to be 
somewhere along a continuum between high and low.

Arab cultures tend to represent the concept of high context (Cohen, 1987; Hecht, Andersen, \& Ribeau, 1989). "A high-context (HC) communication or message is one in which most of the information is either in the physical context or internalized in the person, while very little is in the coded, explicit, transmitted part of the message" (Hall, 1976, p. 91). Hence, nonverbal communication and situational variables are more predominant. The Arabic language tends to be on the high-context end of communication styles because meaning is altered depending on age, status, and the relationship between interactants. Also, physical context may influence the meaning of an interaction based on physical location and time. In his article on Egyptian-American diplomatic relations, cohen (1987) states that "The high-context culture communicates allusively rather than directly. As important as the explicit content of a message is the context in which it occurs, surrounding nonverbal cues and hinted at nuances of meaning" (p.30). High-context communication allows for very enriched communication because of all of the indicators which reinforce meanings to the interactants. Stimuli are received in a variety of ways, rather than in just one or two.

Individuals from the United states tend to use a low-context communication style because they rely on spoken 
and written messages most heavily. "A low-context (LC) somminication is just the opposite (from high-context communication], i.e., the mass of the information is vested in the explicit code (Hall, 1976, p.91). That is, "LC [low-context] messages must be elaborated, clearly communicated, and highly specific" (Andersen, 1988, p. 279). Because of the lack of an explicit context, low-context directness tends to be more lengthy and discrete, therefore entailing more words to transmit a message.

Individuals from Arab countries using high-context communication rely heavily on the use of nonverbal cues (Hall, 1976). Nonverbal communication is inherent in the concept of high-context because of the reliance on other forms of communication beyond the verbal code. "In highcontext, non-Western cultures, rules of behavior are often vague, implicit and tacitly learned simply by 'growing up' in that culture. They are buried or embedded deeply within the context of the culture" (Weaver, 1986, p. 114). The differences in context may be particularly evident during interactions witnessed by members of another culture. The distance one Arab stands to another may communicate animosity, although the interaction may appear to be pleasaric. Furthermore, individuals from the U.S. may observe Arabs talking more loudly than they are accustomed to, standing closer to each other than they are accustomed to, and flailing their arms at one another in what appears 
to be a nasty confrontation. Although there are many possible explanations for this type of interaction, it may be a respectful and enjoyable attempt to persuade one another.

Some of the classic misunderstandings that occur between Arabs and individuals from the U.S. are same-sex and opposite-sex touching in public. Same-sex touching occurs quite frequently, to the extent of men kissing each other in Arab cultures. In the U.S. however, public displays of affection between same-sex friends is not generally accepted. However, touching a member of the opposite sex in public, i.e. holding hands, is acceptable in the United states, but forbidden in Arab countries (Nydel1, 1987). In low-context communication when the direct explicit verbal code is relied upon most heavily, much more weight is given to what is said, rather than what is occurring while the transaction takes place. An example of this is how often people from the U.S. they express the words "I love you." This is certainly not to say that they don't show the people they care about how much they love them, merely that they are accustomed to being reinforced in a verbal manner.

A common difference related to context is the use of direct and indirect verbal communication styles. For example, Arabs communicate in an indirect style. Their verbal style is more circular, infused with statements that allude to the meaning they are attempting to get across, 
without directly stating it (Cohen, 1987). "Directness and especially contradiction are much disliked. It is difficult for a speaker [of a high-context] culture to deliver a blunt 'no.' He wishes to please his interlocutor and will prefer inaccuracy to painful precision" (Cohen, 1987, p. 31). This indirect communication style differs dramatically with individuals from the U.S. who tend to be linear and verbally direct. Arabs may be perceived by individuals from the U.S. as untrustworthy because they appear to be hedging the question by avoiding a direct answer.

To the outsider the high context individual may appear insincere and congenitally suspicious, but this is to define these traits from a culturebound perspective. What may seem to be insincerity and even dishonesty is part of the veneer of elaborate courtesy and evasion essential to preserve social harmony (Cohen, 1987, p.31).

Arabs, on the other hand, may consider individuals from the U.S. rude or aggressive because of their directness (Andersen, 1988). A prime example of this is when Arabs are asked an embarrassing question, i.e. about school or a relationship, they will tend to subtly change the subject or make a joke. To an American, however, the question may not seem embarrassing, and they may probe for an "honest" answer. This difference in communication styles may lead to reduced interactions between Arabs and Americans because of the discomfort which may be experienced by interactants.

Some people experience a greater amount of discomfort when they first arrive in a country other than their native 
land. The stress resulting from being immersed in a different culture may result in what has been termed "culture shock."

The concept of culture shock was first articulated by Kalvero oberg. According to oberg (1960), culture shock is caused by the inability to predict cues in social interaction. Oberg (1972) stated, "culture shock is brought on by the anxiety that results from losing all our familiar signs and symbols of social intercourse" (p. 1). These signs and symbols include the verbal and nonverbal communication styles, customs and norms we are enculturated into in our primary culture. These cues are used in every interaction in which we take part, and help us to organi." and understand the world around us. When we interact in another culture, we do not have these familiar signs and symbols, resulting in the uncomfortable and confusing state of culture shock.

Since Oberg's seminal article, the concept of culture shock has been the subject of many studies. Several authors, (Adler, 1975; Bock, 1970; Condon \& Yousef, 1975; Pusch, 1979; Samovar \& Porter, 1988), have described culture shock as mild discomfort, acute anxiety, frustration, anger, alienation, depression, nervousness, disorientation, helplessness, and questioning of one's competence. For this study, culture shock will be defined as the physiological and emotional responses to the inability to understand the 
symbolic expression of a host culture.

Adler (1975) describes possible defense mechanisms such as repressions, regression, isolation, and rejection that are behavioral manifestations to emotional and physiological responses to differences in culture. Adler (1975) posits that culture shock is not so much the shock of adjusting to the differences in cultures, but the recognition of how culture-bound the individual really is. Adler (1972/1987) goes on to state that the process of culture shock can be viewed as the process of personal growth that may increase the likelihood of positive adaptation. Barna (1976) developed a definition that depends on stimulus response as the indicator of culture shock. "Culture shock [is] the emotional and physiological reaction of high activation that is brought about by sudden immersion in a new and different culture" (p. 1-3).

The issues of acculturation and culture shock are important ones in the study of stressors and coping strategies for international students because many of their stress reactions may be symptoms of these stages of discomfort. Barna (1983) states that "ambiguity, uncertainty and unpredictability-cause the reduced ability to interact within an unknown social structure and lead eventually to culture shock" (p. 31).

Intercultural communication training has developed, in many respects, "to increase the probability of people's 
successful adjustments to another culture" (Brislin et al., 1986, p.14). Intercultural training is offered in many different formats for many different types of sojourners (e.g. students, business people, military personnel). There is no standard program of training, or specific subject matter that is included in intercultural training (Brislin, et al., 1986). Intercultural training may include information on subjects such as culture shock, acculturation, value-orientation training, language training, and logistics, but is not necessarily limited to these subjects. The basic premise of intercultural training is to familiarize a sojourner or host with the culture in which they are going to be in contact (Brislin et al., 1986). "A person in another culture becomes disoriented. Learning that culture increases the predictability of events in that culture, and thus the effectiveness of one's behavior in it" (Triandis, 1986, p. 193). Intercultural communication training is provided to lessen the amount of discomfort and stress, thereby encouraging richer understanding and increased comfort for those involved in a cross-cultural encounter.

Although there is a variety of types of cross-cultural training, Paige and Martin (1983) stress the paramount importance of ethics in cross-cultural training. They state that cross-cultural training must be theory-based, the theory must be strong and rigorous, and the training must 
have an ethical base. These considerations provide useful and accurate training.

"Researchers and practitioners [of cross-cultural training programs] have identified five basic types of programs which are commonly offered to sojourners" (Brislin, et al., 1986, p. 21) "Cognitive Training" stresses a basic information exchange about common facts and occurrences in the host country. Letters, slides and people who have previously travelled to the host country are often utilized. In "Behavior Modification" sojourners think about rewards and punishments in their native cultures, then learn about the rewards and punishments of the host culture. "Experiential Training" immerses sojourners in role-playing activities similar to those they may experience in the host culture. Field trips can also be incorporated into these training sessions. "Cultural Self-Awareness" encourages participants to examine and discuss experiences they may experience in their own cultures. This is especially effective when the destination of the sojourner is unknown. "Attribution Training" teaches sojourners about perceptual differences of behaviors: the how and why of attributions for a wide variety of events.

\section{STRESS AND STRESSORS}

Lazarus (1971) stated that it is "best to consider 'stress' as a general rubric for a large collection of 
related problems, rather than a single narrow concept" ( $p$. 53). Thus, stress can be viewed as a broad category which contains many subclassifications, some of which may be distinct types of stress.

"The term 'stress' has been used to signify environmental agents which disturb structure and function, as well as responses to such agents" (Lazarus, 1971, p. 53). In other words, stress involves harm, challenge, or damage (perceived or real) both to the organism and the environment. Lazarus addresses three possible types of stress: physiological, psychological and social. Physiological stress is that which can be attributed to direct physical deterioration. Social stress occurs when there is a disruption or disturbance of an organization or social system. Psychological stress is a reaction to that which is perceived by a person (consciously or unconsciously) as harmful, threatening, or challenging. The commonality of these realms of stress is that they all interfere with the functioning of the system in some way.

Lazarus (1971, 1985) addresses three possible consequences of differing realms of stress. The first consequence is that a stimulus may be a physiological stressor but not necessarily a psychological stressor. Another consequence is that no matter what type of stress is involved, that experience may be positive or negative. For example, someone may compete in a marathon and experience 
physiological stress, but the experience may be seen as exhilarating to the individual. Also, school examinations may cause a person psychological stress, but the challenge may be thriling. This distinction is sometimes noted as the difference between eustress and distress (Lazarus, 1971). "The third consequence is that coping within one realm of stress. . may have no ameliorating influence with respect to [another realm of] stress reactions" (Lazarus, 1971, p. 54).

As evidenced by the examples of different types of stress, certain events must take place for stress to occur. A stressor is the event that causes the stress reaction, rather than the stimulus alone (Lazarus, 1971). Lazarus relies heavily on the relationship between the organism (person) and the environment. It is his contention that a stimulus must produce given reactions in the organism to be considered a stressor (1971). The specific reactions that may occur, however, are not common to all people.

A universally valid classification of stressors has not been developed. The problem inherent with trying to determine a universally valid classification of stressors is that specific stressors vary because different people react to situations in different ways (Lazarus \& Folkman, 1984). However, this study addresses stressors, or specific everyday situations, that are common for college students. For example, stressors may include taking an examination, 
registering for classes, or answering a question in class. All of these situations are functions of being a student. These events involve one act or function in which the person is the main actor. At this time, there is no set of verbal rules or type of standardization for determining stressors beyond a person experiencing an event in a specific environment. How a person reacts to a stressor depends on how the person perceives the event. An event that may cause a reaction of intense stress for one person, may involve minimal, or even nonexistent, stress to another. The fact that stress is experienced by one person and not necessarily by another may be culturally determined (Lazarus \& Folkman, 1984).

Situations causing stress are likely to occur during the process of acculturation because of a sojourner's interactions with members of the host culture.

"Acculturation occurs through the identification and the internalization of the significant symbols of the host society" (Samovar \& Porter, 1988, p. 345). The process of acculturation is based on interaction with and participation in a host culture. Acculturation takes place through the medium of communication. As sojourners interact in a new sociocultural environment, communicating both verbally and nonverbally, they learn the rules guiding the behavior of the host nationals. These rules reflect the values, attitudes, beliefs, and norms of that society. As the 
process of acculturation progresses, these rules become a part of the repertoire of sojourners, guiding how they adjust to and cope with the differences found in the host culture (Samovar \& Porter, 1988).

It would follow that to the extent sojourners are unfamiliar with a certain culture, they experience a greater amount of stress (Furnham \& Bochner, 1982). If sojourners have developed ways to cope effectively with stress, they will experience less discomfort.

\section{COPING STRATEGIES}

According to Fisher (1986) the it important factor in coping strategies "is the extent to which the presence or absence of control affects the response to stressful conditions" (p. 27). Several typologies address the issue of "control" as a means of coping. These typologies refer to levels of control; thus, coping ability is directly related to the degree of one's control over events.

Averill (1973) distinguished between three types of coping strategies. The "behavioral control" coping strategies are those in which the individual has the ability to effect an alteration or change. "Cognitive control" is the ability to process relevant information to diminish stress. Choosing between many available options is expressed as "decisional control." These three coping strategies reflect a cognitive and interactive approach. 
Lazarus (1971) approaches research in the areas of stress and coping within a slightly different theoretical framework than Averill. In a broad sense, Lazarus defines psychological coping as "the cognitive and behavioural efforts of a person to extricate himself from, or prevent, harm" (Lazarus, 1971, p. 53). In accordance with the previous definition of stress, Lazarus and Folkman (1984) also refer to coping as "the process through which the individual manages the demands of the person-environment relationship that are appraised as stressful" (p. 19). This definition of coping also includes the emotions that are generated through this appraisal. The two main divisions in Lazarus's coping strategies are referred to as prepatory coping and emotion-focused coping (1979). Prepatory coping is a cognitive problem-solving method in which the person focuses on changing his/her relationship to the environment. Common prepatory coping behaviors include pre-departure training and language training. Emotion-focused coping is often used in those situations that are unpredictable or cannot be altered. Defense mechanisms, such as denial, intellectualizing, and avoiding negative thoughts, are usually employed during emotion-focused coping (1979).

Coping strategies are ways in which a person deals with stress. According to Dinges, Lieberman and Tran (1989), coping strategies are ways in which "international students employ to either obviate or decrease the impact of 
stressors" (p. 2). The concept of coping strategies in reference to international students is particularly salient because of the disruption between the person-environment relationship often experienced in living abroad.

\section{HYPOTHESES}

Students who have received effective intercultural training will be better able to predict and control communication-based events. However, other sources of stress that are associated with being a student, regardless of nationality, are not necessarily affected by intercultural training. Consequently, I propose the following hypotheses:

Hypothesis 1:

The average frequency of communication-related stressors relative to non-communication stressors will be negatively correlated with the perceived effectiveness of the students's pre-sojourn intercultural training.

\section{Hypothesis 2:}

The average frequency of emotion-focused coping relative to problem-focused coping will be negatively correlated with perceived effectiveness of intercultural training.

On the other hand, through the long slow process of acculturation, students will learn to predict and control 
communication-related events. Consequently, I propose the following additional hypotheses:

\section{Hypothesis $3:$}

The average frequency of communication-related stressors relative to non-communication stressors will be negatively correlated with the amount of time the student has been in the U.S.

\section{Hypothesis 4:}

The average frequency of emotion-focused coping relative to problem-focused coping will be negatively correlated with the amount of time the student has been in the U.S.

When a situation occurs which requires an ethical judgement or moral consideration, Muslim Arabs rely upon the values that are emphasized in Islam. The Qu'ran offers specific solutions to common situations. Muslim Arab students may experience situations in the U.S. they may not have confronted in their native countries. Therefore, unfamiliar situations experienced by Muslim Arab students in the U.S. will cause stress more frequently if those students strictly practice the rituals of Islam by following Qu'ranic teachings.

Hypothesis 5:

The more actively subjects practice the rituals of Islam, the more frequentIy they will experience stressors. 
The more coping strategies people have at their disposal, the less stress they will experience. So, the greater the repertoire of coping strategies, the lesser amount of stressors a person will experience. By having a larger repertoire of coping strategies, and in turn, fewer situations which cause stress, it is more likely that an individual will be satisfied with living in a foreign country. Accordingly, I propose the following hypotheses relating the variety of coping strategies in the subject's repertoire with the variety of events that will be experienced as stressful, and the subject's overall satisfaction with life in the U.S.:

Hypothesis 6:

Variety of coping strategies will be negatively correlated with the variety of stressors.

Hypothesis 7:

The variety of coping strategies will be positively correlated with satisfaction.

Hypotheses 8:

The variety of events experienced as stressful will be negatively correlated with satisfaction.

Since the literature provides no satisfactory basis for predicting which coping strategies will be most effective, I also propose the following as a research question: 
Researh Question

Which specific coping strategies will correlate most highly with satisfaction with living in the U.S.? 
CHAPTER III

METHOD

PURPOSE OF STUDY

The purpose of this study is to identify the relationships between the most frequently reported stressors, the coping strategies which are reported to be used most often, and the reported level of satisfaction with living in the U.S. for Muslim Arab international students.

\section{SUBJECTS}

\section{Population}

The population is composed of male and female Muslim Arab international students attending colleges and universities in oregon. I used my personal contacts as well as the list of Arab international students available from the international student advisor to contact the subjects. I contacted subjects at Portland State University, University of Portland, Lewis and Clark College and Portland Community College. Also, I approached students who appeared to be speaking Arabic. Potential subjects first answered three questions to make certain they were (1) international students, (2) Arab, and (3) Muslim. If they met these requirements, the subjects filled out a six page 
questionnaire which took approximately twenty minutes. A trained interviewer and or I were present to answer any vocabulary or procedural questions.

The subjects who participated in filling out the questionnaire only qualified as a sample of convenience, yet the selected subjects were treated as a true random sample. Although this is technically a sample of convenience, there is reason to believe that the universities chosen by Muslim Arab international students are determined through processes that bear no relationship to the topic of this study. Accordingly, this sample was analyzed as a sample that was--for the restricted purposes of this study only--representative of Muslim Arab international students generally. Significance levels should be interpreted only as an indicator of the strength of relationships relative to the size of the sample.

\section{INSTRUMENT}

A survey questionnaire was used as the instrument which addressed individual descriptors, level of satisfaction, stressors, and coping strategies. The survey was written in English and responded to by the subjects in English. International students are required to demonstrate a threshold level of proficiency in English for academic purposes before they can be formally admitted to programs of study at institutions of higher education in the U.S. 
Therefore, filling out a questionnaire in English should not have been beyond the subjects' language ability. Some problems in interpretation of the questions surfaced during the pre-test study and, therefore, a few of the questions were deleted or reworded.

\section{DEFINITION OF VARIABLES}

\section{Communication stressors}

A stressor is a communication stressor if it arises from interactions between subjects and others. Communication stressors could range from saying "Hi" to an English speaking person to "Giving a class presentation," to "Asking someone out on a date."

\section{Non-Communication Stressors}

Non-communication are situations such as "studying for a test" and "Pressure to get an A or B" which do not include interactions with others.

Students rate their level of stress in twenty-seven communication and ten non-communication situations they might have encountered using a five-point likert scale. The scale represents how often the situation is reported as stressful: Never (0); Rarely (1); Sometimes (2); Frequently (3); and Always (4). 
Pre-sojourn International Training

Intercultural pre-sojourn training provides an introduction to the host culture for people who are planning to live in another country. To the extent sojourners are unfamiliar with a certain culture, they experience a greater amount of stress (Furnham \& Bochner, 1982). Pre-sojourn training may serve to alleviate some of the unfamiliarity that may be experienced without any training (Brislin et al., 1986). The operationalization of pre-sojourn training is represented by subjects reporting (1) No, or (2) Yes.

Percieved Effectiveness of Pre-Sojourn Intercultural Training

Effective intercultural pre-sojourn training is determined by those subjects who received pre-sojourn intercultural training reporting the level to which they think their training was effective. The operationalization of the effectiveness of pre-sojourn training is based on a scale of: Doesn't apply (0); Not effective at all (1); Somewhat effective (2); Very effective (3).

\section{Emotion-Focused coping}

Emotion-focused factors serve as the regulation of feelings (Lazarus \& Folkman, 1984). This category of coping is often used in those situations that are unpredictable or cannot be altered. Defensive mechanisms, such as denial, intellectualizing, and avoiding negative thoughts are usually employed during emotion-focused coping (Lazarus, 
1979)

\section{Problem-Focused coping}

"Problem-focused factors [are) made up of cognitive and behavioral problems-solving strategies" (Lazarus \& Folkman, 1984, p. 318). Problem-focused coping is a cognitive problem-solving method in which people focus on changing their relationship to the environment. Common problem-focused coping behaviors include pre-departure training and language training.

The following scale is used to operationally represent how frequently thirty-six emotion-focused and ten problemfocused coping strategies have been reportedly used: Never (0); Rarely (1); Sometimes (2); Frequently (3); Always (4).

\section{Time spent in U.S.}

The longer people live in a foreign country, the more likely they are to adjust to the new culture (Samovar \& Porter, 1988). More time in a new culture inherently assumes people will have more experiences with host nationals. Subjects will participate in activities required by living in and being exposed to the new culture. The time subjects spent in the U.S. is measured by years and months.

\section{Satisfaction}

Satisfaction is measured by the following questions:

1. How happy are you living in the U.S.? 
2. If given the chance, how much would you like to remain in the U.S. permanently?

3. Would you recommend that a close friend or relative from your native country come to study here?

The scale to measure satisfaction ranges from: Not at all (0); A little (1); Somewhat (2); A lot (3); Completely (4)

\section{Practice of Islamic Rituals}

This variable is designed as an indication of religiosity Muslim Arab students may feel now that they are in the U.S. It is assumed that the more actively a students practice the rituals of Islam (e.g. Praying, attending the Mosque, etc.), the more closely their values are embedded in traditional Islamic values. The operational measurement has the following range: Not at all (1); Somewhat (2); Completely (3)

\section{Individual Descriptors}

This information includes age, sex, academic level (freshman, sophomore, junior, senior, and graduate, previous intercultural communication training experience, effectiveness of pre-sojourn training if they participated in any, and planned length of stay in the U.S. The individual descriptors are used as control variables, and to provide for possible post-hoc theoretical elaboration. 
ANALYSIS

\section{Variety}

Variety can be measured by the expression $\mathrm{H}=-$ $\sum p_{1} \log \left(p_{i}\right),($ Shannon, 1949; Ritchie, 1991) . H measures the frequency a particular variable is reported and the repertoire of variables reported by an individual. That is, H (stress) measured how often each specific stressor was reported as well as all of the stressors that individuals indicated they have experienced. $\mathrm{H}$ (cope) measured the coping strategies that were reported as those that were employed most often and all of the coping strategies that individuals indicated they have used. The satisfaction variable was then compared to the reported stressors and coping strategies. 
CHAPTER IV

\section{RESULTS}

This chapter explains the results obtained using the Statistical Package for the Social Sciences (SPSSX). All of the tests were run in an attempt to answer the overall question of this study: What are the interrelationships among events reported as frequently stressful, the ways of coping with stress that are reported as most often used, and the reported level of satisfaction with living in the U.S. for Muslim Arab international students?

\section{SCALE RELIABILITIES}

The reliabilities of the five scales used to test hypotheses 1-7 were computed using SPSSx Reliabilities (See Appendix A).

The scale used to measure satisfaction is highly reliable (alpha $=.80)$. There were two scales used for stressors: Communication stressors and non-communication stressors. The communication-related stressor scale is highly reliable (alpha $=.84)$. The non-communication stressor scale is fairly reliable (alpha $=.68$ ). There were two scales used for coping strategies: Emotion-focused coping and problem-focused coping. The emotion-focused 
coping scale is highly reliable (alpha $=.84)$. The problemfocused coping scale is reliable (alpha $=.73$ ).

\section{HYPOTHESIS TESTS}

The eight hypotheses related to the overall question of this study were tested using the sPssx program correlations. The communication-related stressor scale is correlated with the non-communication scale at $r=.62, p_{.}>01$. Adjusted for scale reliabilities, the two scales are perfectly correlated (adjusted $r=1.0$ ), suggesting that both measure a single underlying construct. However, to remain consistent with the hypotheses, the two scales will be separately analyzed.

The emotion-focused coping scale is correlated with the problem-focused coping scale at $r=.49, \mathrm{p}_{\mathrm{f}}>01$. Adjusted for scale reliabilities, the two scales are highly correlated (adjusted $r=8.0$ ), suggesting that both of these scales also measure a single underlying construct. However, to remain consistent with the hypotheses, the two scales will be separately analyzed.

\section{Hypothesis 1}

The average frequency of com-munication-related stressors relative to noncommunication stressors will be negatively correlated with the perceived effectiveness of the students's pre-sojourn intercultural training. 
The correlation between communication-related stressors and perceived effectiveness of pre-sojourn intercultural training is $r=-.06$, not significant (n.s.). The correlation between non-communication stressors and perceived effectiveness of pre-sojourn intercultural training is $r=-.11$, n.s. The ratio of communicationrelated stressors to non-communication stressors is correlated with the perceived effectiveness of intercultural training, $r=-.01$, n.s. The null hypothesis cannot be rejected.

Hypothesis 2

The average frequency of emotion-focused coping relative to problem-focused coping will be negatively correlated with perceived effectiveness of pre-sojourn intercultural training.

The correlation between the frequency of emotionfocused coping and perceived effectiveness of pre-sojourn intercultural training is $r=-.05, \mathrm{n} . \mathrm{s}$. The correlation between the frequency of problem-focused coping and perceived effectiveness of pre-sojourn intercultural training is $r=.19, \mathrm{p}<.06$. The ratio of emotion-focused coping to problem-focused coping is correlated with the perceived effectiveness of pre-sojourn training, $r=-.15$, n.s. The null hypothesis cannot be rejected with confidence. 
Hypothesis 3

The average frequency of communication-related stressors relative to non-communication stressors will be negatively correlated with the amount of time the student has been in the U.S.

The correlation between communication-related stressors and the amount of time the student has been in the U.S. is $r$ $=-.04$, n.s. The correlation between non-communication stressors and the amount of time the student has been in the U.S. is $r=.01$, n.s. The ratio of communication-related stressors to non-communication stressors is correlated with the amount of time spent in the U.S., $r=-.05$, n.s. The null hypothesis cannot be rejected.

\section{Hypothes is 4}

The average frequency of emotion-focused coping relative to problem-focused coping will be negatively correlated with the amount of time the student has been in the U.S. The correlation between the frequency of emotionfocused coping and the amount of time a student has spent in the U.S. is $r=.16$. The correlation between the frequency of problem-focused coping and amount of time the student has been in the U.S. is $r=.19, \underline{p}<.05$. The ratio of emotionfocused coping to problem-focused coping is correlated with the amount of time spent in the U.S., $r=-.03$, n.s. Both coping scales are related to time spent in the U.S. The null hypothesis cannot be rejected. 
Hypotheses 5

The more actively subjects practice the rituals of Islam, the more frequently they will experience stressors.

The correlation between how actively subjects practice the rituals of Islam and the frequency of all reported stressors is $\mathrm{r}=.16, \mathrm{p}<.06, \mathrm{n} . \mathrm{s}$. The null hypothesis cannot be rejected.

Hypotheses 6

Variety of coping strategies -- H(cope) -- will be negatively correlated with the variety of stressors $--\mathrm{H}$ (stress).

The correlation between the variety of coping strategies a person experiences and the variety of stressors a person experiences is $r=.31$. Because the correlation is significantly positive, and not negative, the null hypothesis cannot be rejected.

Hypothesis 7

The variety of coping strategies -- H(cope) -- will be positively correlated with satisfaction.

The correlation between the variety of coping strategies and successful outcomes is $r=-.07, \mathrm{n} . \mathrm{s}$. The null hypothesis cannot be rejected.

Hypothesis 8

The variety of events experienced as stressful -H(stress) -- will be negatively correlated with 
satisfaction.

The correlation between the variety of events experienced as stressful and successful outcomes is $r=-$ .07 , n.s. The null hypothesis cannot be rejected.

\section{RESEARCH QUESTION}

\section{Research Question:}

Which specific coping strategies will correlate most highly with satisfaction with living in the U.S.?

Listed in Table II are the part correlations and part correlations squared for items selected as significant by step-wise regression determined by multiple regression using SPSSx. Table 1 represents each item's unique contribution to the dependent variable's total explained variance. The positive part correlations for variables $\mathrm{C} 12$ and $\mathrm{Cl} 4$ represent coping strategies most frequently used by those subjects who reported being highly satisfied with living in the U.S. The negative part correlations for variables c38, C30 and C26 represent those coping strategies which are most frequently used by those subjects who reported being the least satisfied with living in the U.S. 
TABLE II

SATISFACTION INDICATORS

\begin{tabular}{|l|c|c|}
\hline \multicolumn{1}{|c|}{ Variable Name } & Part correlation & $\begin{array}{c}\text { Part Correlation } \\
\text { Squared }\end{array}$ \\
\hline $\begin{array}{l}\text { C12 = Try to look } \\
\text { on the bright side. }\end{array}$ & .38 & .14 \\
\hline $\begin{array}{l}\text { C14 = Express anger } \\
\text { to those who caused } \\
\text { problem. }\end{array}$ & .17 & .03 \\
\hline $\begin{array}{l}\text { C30 = Refuse to take } \\
\text { situation too } \\
\text { seriously. }\end{array}$ & -.17 & .03 \\
\hline $\begin{array}{l}\text { C38 = Imagine a } \\
\text { better place or } \\
\text { time. }\end{array}$ & -.12 & .02 \\
\hline $\begin{array}{l}\text { C26 }=\text { Change things } \\
\text { to turn out alright. }\end{array}$ & -.10 & .01 \\
\hline
\end{tabular}


CHAPTER V

DISCUSSION

This chapter interprets the results determined for each of the hypotheses and for the research question. This discussion will attempt to answer the overall question of this study: What are the interrelationships among events reported as frequently stressful, the ways of coping with stress that are reported as most often used and the reported level of satisfaction with living in the U.S. for Muslim Arab international students?

A regression test revealed positive and negative patterns for the results of the research question: Which specific coping strategies will correlate most highly with satisfaction with living in the U.S.? The coping strategies used most frequently by subjects who are satisfied with living in the U.S. are C12, "Try to look on the bright side," and C14, "Express anger to those who caused problem." These coping strategies suggest that those subjects who think positively and assert themselves to deal with problems directly are more satisfied with living in the U.S. Looking on the bright side allows one to keep a positive outlook and not get unduly depressed or upset. If someone is looking for something good in a situation, he or she will probably 
find it (Lazarus \& Folkman, 1984). Expressing anger to those who caused the problem suggests dealing directly with a problem, and not allowing the issue to become exaggerated or out of control. There is no worrying or wondering about what is going to happen to resolve the situation. Fisher (1986) states the most important factor in coping strategies "is the extent to which the presence or absence of control affects the response to stressful conditions" (p. 27). Therefore, coping directly with a stressful situation may give a person a sense of power and control which she or he would not experience if he or she ignored the situation, left it up to fate, or prayed for Divine intervention. confronting and addressing stressful situations allows one to maintain control.

The subjects who used coping strategies which focus on fantasizing or wishful thinking were the least satisfied with living in the U.S. These results suggest that the subjects who do not address a stressful situation, and thereby relinquish their control over the situation, are unhappy because they are not effectively dealing with a situation they perceive as stressful. Coping strategies C38, "Imagine a better place or time," and c30, "Refuse to take situation too seriously," suggest a pattern of avoidance and denial. The subjects leave themselves open for mental pain and anguish because they refuse to engage in productive behavior to effectively cope with the stressful 
situation (Lazarus \& Folkman, 1984). C26, "Change things to turn out alright," also resulted in low satisfaction with living in the U.S. This may be due to having to change behaviors or emotional responses which can often be difficult and uncomfortable. According to Lazarus and Folkman (1984) "Culturally derived values and beliefs serve as norms that determine when certain behaviors and feelings are appropriate and when they are not" (p. 165). Thus, one may have to change things to turn out alright because behaviors expressed in the primary culture are not appropriate in the host culture and/or emotional responses do not elicit the same reactions in host nationals as in people in one's native culture.

None of the hypotheses that were predicted in this study were supported. Although there are non-significant results for all of the hypotheses, a variety of possible explanations of the results of this study will be explored in the following discussion. However, it is important to remember that explanations are based on possible interpretations, and not on statistical significance.

Effective pre-sojourn intercultural training does not decrease the communication-related stressors experienced by subjects (Hypothesis 1). The frequency of emotion-focused coping does not decrease when the perceived effectiveness of pre-sojourn intercultural training increases (Hypothesis 2). The results of hypotheses 1 and 2 suggest that the 17 
subjects who reported receiving pre-sojourn intercultural training may have had training that was primarily logisticbased. Yet, it is difficult to interpret these results with such a small number of subjects reporting having any intercultural training.

with its roots in cultural anthropology, psychology, and sociology, intercultural communication training is in its infancy as a field of study (Paige, 1986). There is a variety of formats and materials that are included in intercultural training sessions (Brislin et al., 1986). The training may include solely logistical training about how to perform tasks in the host culture, or may offer in-depth value-orientation training and role-playing (Brislin et al., 1986; Paige, 1986). Most intercultural communication training includes some logistical material and some valueorientation training. For example, in the oregon state System of Higher Education, a student at Portland state University who is travelling on an overseas exchange program through NICSA receives a handout, which is composed of largely logistical information, and may attend a meeting for approximately two hours with students who have just returned from an exchange program (Dawn White-Personal Communication $03-31-92)$

The results of hypothesis 2 reveal that not only does problem-coping not decrease, but it appears to slightly increase. That is to say, those subjects who perceived pre- 
sojourn intercultural training to be effective used problemfocused coping strategies most often. This relationship suggests that the training supplied focus on situations where the subject did not have to react immediately. Instead, subjects used coping strategies such as 142 , "Practice what I will say or do," C24, "Try not to act too hastily" and C16, "Change my way of doing things." This is not to say that knowledge about how to perform these tasks is not helpful, but logistical training alone does not offer solutions or explanations of emotion-based problems.

The problem-focused coping strategies also involve activities rather than feelings. Problem-focused variables do not deal with changing personal values or beliefs in order to cope with a situation as emotion-focused coping strategies do (Lazarus \& Folkman, 1984). Rather, problemfocused coping suggests analyzing a situation and determining the most effective way to deal with a situation. Analyzing a situation in a clear-minded fashion is difficult when emotions are involved.

If the pre-sojourn training offered information about in-depth emotional subjects such as culture shock, acculturation, and value-orientations, emotion-focused coping may have increased as the perception of effective pre-sojourn training increased. Consequently, the fact that emotion-focused coping was not correlated with effective pre-sojourn intercultural training also suggests that 
training about the issues of culture shock, acculturation, and value-orientations, for example, was probably not offered to the subjects of this study.

Hypothesis 3 predicted a negative correlation between communication-related stressors, relative to noncommunication stressors, and time spent in the U.S. According to this hypothesis, students who have lived in the U.S. for a short period of time would have reported a high level of communication-related stressors, and students who have lived in the U.S. for a long period of time would have experienced fewer communication-related stressors. In fact, those who have lived in the U.S. for a longer period of time did not report a lower level of communication-related stressors than those who have only lived in the U.S. for a short while. Continued political strife in the Middle East may be one reason that Muslim Arab students do not appear to experience less stress the longer they have been in the U.S. Coupled with this issue is the idea that strong family ties are subject to strain while a student studies in the U.S. (Nydell, 1987). The subjects in this study, predominately male, are powerless to fulfill their family and social obligations while they are in the U.S. Arab cultures are extremely obligatory when compared to other cultures (Condon \& Yousef, 1975). Specific duties and responsibilities are expected to be fulfilled without question from the person performing them. Muslim Arabs studying in the U.S. are not 
in the position to help their families, or to protect them from the constant threat of the conflicts that abound in many Middle Eastern countries. Fulfilling family obligations is paramount for members of cultures, such as those in the Middle East, who subscribe to a lineal family value-orientation (Condon \& Yousef, 1975). Stress may become more intensified the longer Muslim Arab international students Iive away from their native countries because they are usually unable to contribute emotional and/or financial support to their families and friends.

Many subjects reported they rarely experience stress for S14, "Speaking English." For a cultural group that uses a vastly different alphabet and grammar, this appeared as an unusual result. Language training in their native countries and pre-sojourn training that may have been based primarily on language-use and logistics, may have greatly increased sojourner's abilities to speak English comfortably.

The results of hypothesis 4 did not support the idea that the frequency of emotion-focused coping is negatively correlated, relative to problem-focused coping, with the amount of time a student has lived in the U.S. The less time a student has Iived in the U.S., the more frequentIY she or he would use emotion-focused coping strategies; or the more time a student has spent in the U.S., the less frequently he or she would use emotion-focused coping. The results indicated emotion-focused coping and problem-focused 
coping are both related to length of time spent in the U.S. But, neither category of coping strategies has strong correlations with length of time spent in the U.S.

The logic of hypothesis 4 was based on research conducted on acculturation and culture shock. Acculturation is the process of learning and adjusting to a new cultural environment over a period of time (Samovar \& Porter, 1988). Culture shock usually occurs during the first six months spent in a host culture (Barna, 1983). During these first few months, feelings and emotions are strained because students experience situations that are unfamiliar and unpredictable. International students do not usually have family members or close friends to rely on for emotional support and validation. Students who are experiencing the intense discomfort associated with culture shock may use more emotion-focused coping strategies to try and alleviate emotional strain during these times. However, because emotion-focused coping did not appear to decrease over time, this suggests that emotional issues were a constant challenge for the Muslim Arab international students who formed the research sample in the study. The use of problem-focused coping strategies is consistent throughout time, because these coping strategies are mainly functions which aid in completing tasks (Lazarus \& Folkman, 1984). Hypothesis 6 predicted that the variety of coping strategies would be negatively correlated with the variety 
of stressors. The results of this hypothesis reflected the opposite of the prediction. As the variety of coping strategies increased or decreased, so too did the variety of stressors. Therefore, those subjects who reported a high variety of coping strategies also reported a high variety of stressors. And, those subjects who reported a low variety of coping strategies also reported a low variety of stressors. The original hypothesis was developed on the premise that the more coping strategies one has at his or her disposal, the fewer situations a person will experience as stressful. Thus, a high variety of coping strategies would preclude one from experiencing a high variety of stressors. However, it appears that those subjects who reported using a high variety of coping strategies, did so because they had a high variety of stressors. Also, those subjects who used a low variety of coping strategies did so because they experienced a low variety of stressors. Thus, coping strategies may function as a direct response to stress.

Hypothesis 7 was based on the idea that the greater the variety of coping strategies, the greater would be the level of satisfaction with living in the U.S.; conversely, the lower the variety of coping strategies, the lower would be the level of satisfaction with living in the U.S. A large variety of coping strategies was assumed to be preventive against stressors, and hence, would lead to a higher level 
of satisfaction. Yet if, as suggested by the results of hypothesis 6, the Muslim Arab international students in this study use coping strategies to the degree that they experience stressors, it is logical that there would not be a positive relationship between coping strategies and satisfaction. In other words, a high variety of coping strategies infers a high variety of stressors, which would lead to a lower level of satisfaction. Yet it is important to remember that there was no significant correlation between the variety of coping strategies and satisfaction. Hypothesis 8 predicted a negative relationship between the variety of stressors and satisfaction. There was no significant correlation between the variety of stressors and satisfaction. Thus, hypotheses 7 and 8 may conflict with the results of hypothesis 6 because the measure used to determine satisfaction did not get at whether or not people are happy with Iiving in the U.S.

Satisfaction with living in the U.S. is an ambiguous issue. The extent of family obligations for Muslim Arabs generally does not allow for individuals to consider their own comfort and desires over family expectations (condon \& Yousef, 1975; Nydell, 1987). It is important to remember that family obligations require Muslim Arab international students to plan on returning to their native countries and fulfilling their responsibilities. 
Interpreting the results of the question of satisfaction is complicated by extenuating circumstances that may have biased the answers given by the subjects. For example, some subjects expressed a desire to remain in the U.S. but reported that they didn't indicate that on the questionnaire because they are unable to remain away from their families. Furthermore, several subjects stated that Iife for a student is harder in the U.S. than it is in their native countries. Students often have to work or find some way to support themselves while they are attending a university in the U.S. In the Middle East, it is traditional for students to attend college directly after high school while they are still living with their parents. Many universities do not require students to pay tuition so costs aren't an issue. In general, parents pay for all of the students' living expenses while they are still attending college. The parents take care of the finances because it is considered their responsibility. In the U.S., an international student not only has to pay tuition, but must have enough financial support to pay for books, living expenses, food, etc. Tuition for international students at state universities is approximately 3 times the rate of tuition for local U.S. citizens and residents. International students cannot qualify for financial aid unless they become resident aliens or U.S. citizens. On the average, the process for becoming a resident takes 2 years, 
and certain conditions must be met. Citizenship is more difficult to acquire and takes additional time.

Hypothesis 5 was based on the premise that Muslim Arabs who practice the rituals of Islam actively would experience a greater amount of stressors while living in the U.S. because of the vast cultural differences they would be exposed to. The basis of this prediction was the difference between living in a sacred culture where religion is embedded into the whole cultural structure, and living in a secular culture where a separation of church and state exists. The results of this hypothesis were not significant, but were indicative of some relationship between practicing the rituals of Islam and experiencing stressors. An interesting point to consider is that increased religiosity could be due to the idea that individuals experience a great deal of discomfort as they realize just how culture-bound they are to their native culture (Adler, 1975). Thus, rather than severing their connections with their native culture, the Muslim Arab students in this study may be inclined to embrace that which is familiar to them. Practicing the rituals of Islam more actively during stressful times may function as a means for reducing the influence of unfamiliar and unpredictable situations. Islam may function as a familiar resource during times of stress, offering specific solutions to particular situations, a moral guideline, which may help a 
student cope with stressful situations. The common Arabic phrase Inshaa Allah, God's will be done, shifts the responsibility away from the person and places it on the supernatural: Allah. Muslims subscribe to the valueorientation that people are controlled by the supernatural (Condon \& Yousef, 1975). Relying on Allah's will may encourage a Muslim to practice his or her faith more actively in the hope that Allah will provide the solution to one's stressful situation.

\section{LIMITATIONS}

The Muslim a. international students in this study are members of many Arab nation-states and several Islamic factions in which differences inevitably exist. The term Muslim Arab was used to acknowledge that these subjects are more similar to each other than to cultural groups who are neither Arab nor Muslim. To consider all Muslim Arabs as one uniform cultural group, however, would be an overgeneralization. This may not be a sociopolitical identity, but the term Muslim Arab does describe a religious and Iinguistic identity.

As a non-Muslim Arab female, my opportunities for candid responses were limited. Although I always had a male Muslim Arab student with me when administering the questionnaire, I was an unknown outsider asking questions of a personal nature. As it was a long questionnaire, subjects 
may have randomly filled in answers to complete the process more quickly. I am not assuming that subjects would purposely lie but, they may have felt they had nothing to gain from filling out the questionnaire carefully. According to Babbie (1992), artificiality is always a concern in social science research. Answers that make the subject appear "better," in this case, as though they experience fewer stressors or do not have a need for certain coping strategies, may have been reported. Many subjects appeared confused when they were asked to indicate frequencies instead of whether or not they had actually experienced stressors and coping strategies. Although the previous two theses (Kurogi, 1990; Laing, 1990) written on this subject yielded statistically significant results, the self-report method may have caused confusion for the subjects. Finally, there is not a clear methodological distinction between stressors and coping strategies.

\section{SUGGESTIONS FOR FURTHER RESEARCH}

Further culture-specific research needs to be conducted on the complex cultures of the Middle East. Much of the research to date focuses on the political conflicts that have occurred rather than on the behaviors, values, rituals, and beliefs of the people. Culture-specific research is always revealing in that it uncovers the unique characteristics of a given people. However, more 
informative research could be gathered by conducting ethnographic research utilizing a native speaker who is knowledgeable about the traditions and social structure of a particular cultural group.

Further research in the fields of stressors and coping strategies also needs to be conducted. The stressor and coping strategy scales that have been developed cannot be divided into various categories such as communicationrelated stressors, non-communication stressors, emotionfocused coping, and problem-focused coping. The communication and non-communication stressor scales were highly intercorrelated which suggest the scales are not measuring different constructs. The emotion-focused and problem-focused coping strategy scales were also highly intercorrelated which suggests these scales were not measuring substantially different types of constructs. Additional variables that represent the intensity and frequency of experiencing stressors and coping strategies would also be useful.

Research in the development of a standard intercultural training program would also be beneficial for future studies. If sojourners and hosts could consistently be exposed to particular material the intensity of particular stressors might be lessened and the ability to cope with unfamiliar situations might be increased. However, because much of this research is so new, there are simply not enough 
longitudinal studies to determine what is most effective for a given culture (Brislin et al., 1986). Culture-specific research would need to address both the native culture and the host culture. Certainly it is fair to say that the abundance of existing culture-specific literature about Americans, British and Japanese, for example, cannot be applied to the peoples of the Middle East. Although there may be similarities in value-orientations and belief systems for various cultures, values and beliefs are manifested in different ways. Each cultural group has certain basic human similarities, but each cultural group is also distinctly unique in how its members have developed and passed on these similarities to other generations. Culture-general research is informative on the surface level about many issues, but simply does not provide the specificity that culturespecific research does.

\section{SUMMARY}

overall, there are still many questions that need to be answered when considering the situation of Muslim Arab international students studying at universities in the U.S. However, the information gained about the Muslim Arabs in this study may be generalizable to others coming to the U.S. to study.

Presently, pre-sojourn intercultural training does not aid in reducing the stressful situations experienced by 
these subjects (Hypothesis 1). The frequency of emotionfocused coping does not decrease when the perceived effectiveness of pre-sojourn intercultural training increases (Hypothesis 2). According to Brislin et al. (1986), there is still a wide variety of materials and formats being used in cross-cultural training. "This approach means that there are no materials of which many trainers are aware and that they have used in actual programs" (Brislin et al., 1986, p. 23). Additional time spent living in the U.S. does not reduce the communicationrelated stressors Muslim Arab students experience (Hypothesis 3). Although research indicates that the longer people live in a foreign country, the more they learn about the rules and norms and, therefore, become acculturated (Samovar \& Porter, 1988), the additional situations a Muslim Arab international student may have to deal with could override the positive effects of time. The frequency of emotion-focused coping does not substantially decrease with the longer amount of time a student has lived in the U.S. (Hypothesis 4 ).

Stress is a part of any student's life. For the Muslim Arab international students in this study, the basic value system provided by. Islam appears to be related to coping with stressful situations while living in the U.S. (Hypothesis 5). 
As the variety of coping strategies increases, the variety of stressors does not decrease (Hypothesis 6). Rather, as the variety of stressors increases, so also does the variety of coping strategies. It appears that students who experience more stressors respond by using more coping strategies. This suggests coping strategies are used in response to stressors rather than as prevention against them.

Satisfaction was correlated with neither coping strategies nor stressors. One would expect satisfaction to be positively related to coping strategies (Hypothesis 7), but there was no relationship. One would also expect satisfaction to be inversely related to stressors (Hypothesis 8 ), but there is no relationship. Satisfaction was measured by the extent to which subjects would want to remain in the U.S., and if they would recommend that a loved one study in the U.S. Based on the highly obligatory social structure that exists in Muslim Arab cultures of the Middle East, remaining away from one's family and friends may not have been acceptable. If students wanted to remain in the U.S., they may not have reported this on the questionnaire. "Loyalty to one's family takes precedence over personal needs" (Nydell, 1987, p.17). Difficulties associated with living in the U.S. as an international student may have also led subjects to report they would not recommend that a loved one study in the U.S. 
In conclusion, there are three important results that can be drawn from this study. First, with respect, at least, to the Muslim Arab international students in this study, there is no way to empirically discriminate between different categories of stressors or different categories of coping strategies. Second, denial and wishful thinking are not effective coping strategies. Third, direct problem solving is clearly the most effective way for the Muslim Arab international students in this study to cope with stressors while living in the U.S. 
Adler, P. S. (1987). Culture shock and the cross-cultural learning experience. In L. F. Luce \& E.C. Smith (Eds.), Toward internationalism (pp. 14-35). Cambridge, MA: Newbury. (Original work published 1972).

Adler, P. S. (1975). The transitional experience: An alternative view of culture shock. Journal of Humanistic Psychology, 15 (4), 13-23.

Almaney, A. R., \& Alwan A. J. (1982). Communication with the Arabs: A handbook for the business executive. Prospect Heights, IL: Waveland Press.

Andersen, P. A. (1988). Explaining intercultural differences in nonverbal communication. In L. A. Samovar \& R. E. Porter (Eds.), Intercultural communication: A reader (5th ed.) (pp. 44-54). Belmont, $C A$ : Wadsworth.

Averill, J. R. (1973). Personal control over aversive stimuli and its relationship to stress. Psychological Bulletin, 80, 286-303.

Babbie, E. (1992). The practice of social research (6th ed.). Belmont, CA: Wadsworth.

Barna, L. M. (1976). How culture shock affects communication. Communication, $\underline{5}(1), 1-18$.

Barna, L. M. (1983). The stress factor in intercultural relations. In R. W. Brislin, D. Landis, \& J. Brandt (Eds.) Handbook of intercultural training. (Vol. 2, pp. 19-49). New York: Pergamon Press.

Bock, P. (1970). Culture shock. New York: Alfred A. Knopf.

Brislin, B. W., Cushner, K, Cherrie, C., \& Yong, M. (1986). Intercultural interactions A practical quide. Newbury Park, CA: Sage.

Cavendish, R. (1984). An illustrated Encyclopedia of mythology. New York: Crescent. Cohen, R. (1987). Problems of intercultural communication in EgyptianAmerican diplomatic relations. International Journal of Intercultural Relations. 11, 29-48. 
Condon, J. C., \& Yousef, F. (1975). An introduction to intercultural communication. Indianapolis, IN: BobbsMerrill.

Dinges, N. G., Lieberman, D. A. \& Tran, Q. D. (1989, August). Stressors and coping strategies among international students: Implications for classroom practice. Paper presented at the World communication Association Convention, Singapore.

Fisher, S. (1986). Stress and strategy. Hillsdale, NJ: Lawrence Erlbaum Associates.

Fontaine, G. (1986). Roles of social support systems in overseas relocation: Implications for intercultural training. International Journal of Intercultural Relations. 10, 361-378.

Furnham, A., \& Bochner, S. (1982). Social difficulty in a foreign culture: An empirical analysis of culture shock. In S. Bochner (Ed.), cultures in contact (pp. 161-198). New York: Pergamon Press.

Hall, E. T. (1976). Beyond culture. New York: Anchor Books/Doubleday.

Hamidullah, M. (1980). Introduction to Islam (5th ed.). Chicago: Kazi.

Hawting, G. R. (1987). The first dynasty of Islam: The Umayyad caliphate. Carbondale, Il: Southern Illinois University Press.

Hecht, M. L., Andersen, P. A. \& Ribeau, S. A. (1989). The cultural dimensions of nonverbal communication. In $M$. K. Asante \& W. B. Gudykunst (Eds.), Handbook of international and intercultural communication (pp. 163185). Newbury Park, CA: Sage.

Heller, S. (1991, January 30). Some Jewish students break ranks with liberal groups; at Dearborn, Arab Americans' re distracted, saddened'. The Chronicle of Higher Education, pp. A1, A29, A32.

Hoopes, D. S. (1979). Intercultural communication concepts and the psychology of intercultural experience. In $M$. D. Pusch (Ed.), Multicultural education: A cross cultural training approach (pp. 9-38). Yarmouth, Maine: Intercultural Press. 
Johnson, J. D., \& Tuttle, F. (1989). Problems in intercultural research. In M. K. Asante \& W. B. Gudykunst (Eds.). Handbook of international and intercultural communication (pp. 461-483). Newbury Park, CA: Sage.

Khalidi, T. (1975). Islamic historiography: The histories of Mas'udi. Albany: State University of New York Press.

Kim, Y. Y. (1989). Intercultural adaptation. In M. K. Asante \& W. B. Gudykunst (Eds.). Handbook of international and intercultural communication (pp. 275294). Newbury Park, CA: Sage.

Kluckholn, F. B., \& strodtbeck, F.L. (1961). Variations in value orientations. New York: Row and Peterson.

Kurogi, A. (1990). Communication stress and coping strategies among Japanese university students in the United states. Unpublished master's thesis. Portland State University, Portland, OR.

Laing, Q. L. (1990). Communication stressors and coping strategies among Chinese students in the United states. Unpublished master's thesis. Portland State University, Portland, OR.

Landau, J. M. (1990). The politics of Pan-Islam. New York: oxford.

Lapidus, I. M. (1988). A history of Islamic societies. Cambridge: Cambridge University Press.

Lazarus, R. S. (1971). The concept of stress disease. In Levi, L. (Ed.), Society, stress and disease (Vol. 1, pp. 53-60). London: Oxford University Press.

Lazarus, R. S. (1979, November). Positive denial: The case for not facing reality. Psychology Today, pp. 44-60.

Lazarus, R. S. (1985). Stress and coping: An anthology (2nd ed.). New York: Columbia University Press.

Lazarus, R. S., \& Folkman, S. (1984). Stress, appraisal, and coping. New York: Springer Publishing Company.

Musallam, B. (1983). The Arabs: A living history. London: Harvill Press Ltd. 
Nydell, M. K. (1987). Understanding Arabs: A guide for westerners. Yarmouth, MA: Intercultural Press.

Oberg, K. (1960). Culture shock: Adjustment to new cultural environments. Practical Anthropology, $7,170-179$.

oberg, K. (1972). Culture shock and the problem of adjustment to new cultural environments. In D. S. Hoopes (Ed.), Readings in intercultural communication, Vol. II. Pittsburgh: Regional Council for International Education.

Paige, R. M. (Ed.) (1986). Cross-cultural orientation: New conceptualizations and applications. Lanham, MD: University Press of America.

Paige, R. M., \& Martin, J.N. (1983). Ethical issues and ethics in cross-cultural training. In $D$. Landis \& $R$. W. Brislin (Eds.). Handbook of intercultural training, (Vol. 2, pp. 36-60). New York: Pergamon Press.

Pusch, M. D. (1979). Multicultural education: A crosscultural training approach. Yarmouth, Maine: Intercultural press.

Ritchie, L. D. (1991) . Communication concepts 2: Information. Newbury Park, CA: Sage.

Samovar, L. A., \& Porter, R. E. (1988). Intercultural communication: A reader (5th ed.). Belmont, CA: Wadsworth.

Sauders, J. J. (1965). A history of medieval Islam. London: Routledge and Kegan Paul.

Shannon, C. (1949). The mathematical theory of communication. In C. Shannon \& W. Weaver (Eds.), The mathematical theory of communication. Urbana: University of Illinois Press.

Smith, w. C. (1957). Islam in modern history. New York: New American Library of World Literature.

Triandis, H. C. (1986). Approaches to cross-cultural orientation and the role of the culture assimilator training. In R. M. Paige (Ed.), Cross-cultural orientations, (pp. 193-222). Lanham, MD: University Press of America.

Weaver, G. R. (1986). Understanding and coping with crosscultural adjustment stress. In R. M. Paige (Ed.), Cross-cultural orientation, (pp. 111-146). Lanham, MD: University Press of America. 
APPENDIX A

VARIABLE CATEGORIES AND RELIABILITIES 
VARIABLE CATEGORIES AND RELIABILITIES

SATISFACTION

\begin{tabular}{|c|c|}
\hline & 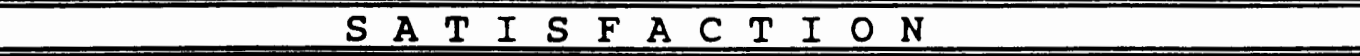 \\
\hline 1. & (SAT) 1) How happy are you living in the U.S? \\
\hline 2 . & $\begin{array}{l}\text { (SAT 2) If given the chance, how much would you } \\
\text { like to remain in the U.S. permanently? }\end{array}$ \\
\hline 3. & $\begin{array}{l}\text { (SAT } 3) \text { How strongly would you recommend a close } \\
\text { friend or relative from your native country come to } \\
\text { study here? }\end{array}$ \\
\hline & Satisfaction alpha $=.80$ \\
\hline & 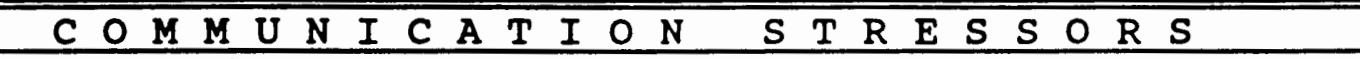 \\
\hline 1. & (SI) Asking a question in class. \\
\hline 2. & (s3) Giving a class presentation. \\
\hline 3. & (s8) Peer pressure to take part in social activities. \\
\hline & (S12) Disagreements with instructor $(\mathrm{s})$. \\
\hline 5. & (s13) Personal contact with the faculty. \\
\hline 6. & (S14) Speaking English. \\
\hline & (S15) Living among strangers for the first time. \\
\hline & (S16) standing up for my own beliefs. \\
\hline & (S17) Being called on in class. \\
\hline 10. & (s18) Making an appointment to meet a professor. \\
\hline 11. & $\begin{array}{l}\text { (S19) Knowing when it is appropriate to make a } \\
\text { comment in class. }\end{array}$ \\
\hline 12. & (s20) Registering for classes. \\
\hline 13 & $\begin{array}{l}\text { (S21) Asking someone I do not know to go to a social } \\
\text { activity. }\end{array}$ \\
\hline 14 & $\begin{array}{l}\text { (S23) Asking non-Arab students to explain class } \\
\text { material. }\end{array}$ \\
\hline 15. & (s24) Asking Arab students to explain class material. \\
\hline 16. & $\begin{array}{l}\text { (S25) Discussing cultural problems with non-Arab } \\
\text { students. }\end{array}$ \\
\hline 17. & $\begin{array}{l}\text { (S26) Discussing cultural problems with Arab } \\
\text { students. }\end{array}$ \\
\hline 18 . & $\begin{array}{l}\text { (\$27) Discussing personal life problems with non-Arab } \\
\text { students. }\end{array}$ \\
\hline 19. & $\begin{array}{l}\text { (S28) Discussing personal life problems with Arab } \\
\text { students. }\end{array}$ \\
\hline 20 & $\begin{array}{l}\text { (S30) Socializing with individuals from the opposite } \\
\text { sex. }\end{array}$ \\
\hline 21. & (s31) Asking someone out on a date. \\
\hline & (S32) Having an intimate relationship. \\
\hline 23 . & $\begin{array}{l}\text { (\$33) Responding to negative remarks about my } \\
\text { culture. }\end{array}$ \\
\hline 24 & $\begin{array}{l}\text { (S35) Asking for career/professional advice from } \\
\text { faculty and school staff. }\end{array}$ \\
\hline 25. & (S36) Dealing with roommate problems. \\
\hline & (s37) Getting needed health care. \\
\hline & Communication-ralated stressors alpha -.84 \\
\hline
\end{tabular}




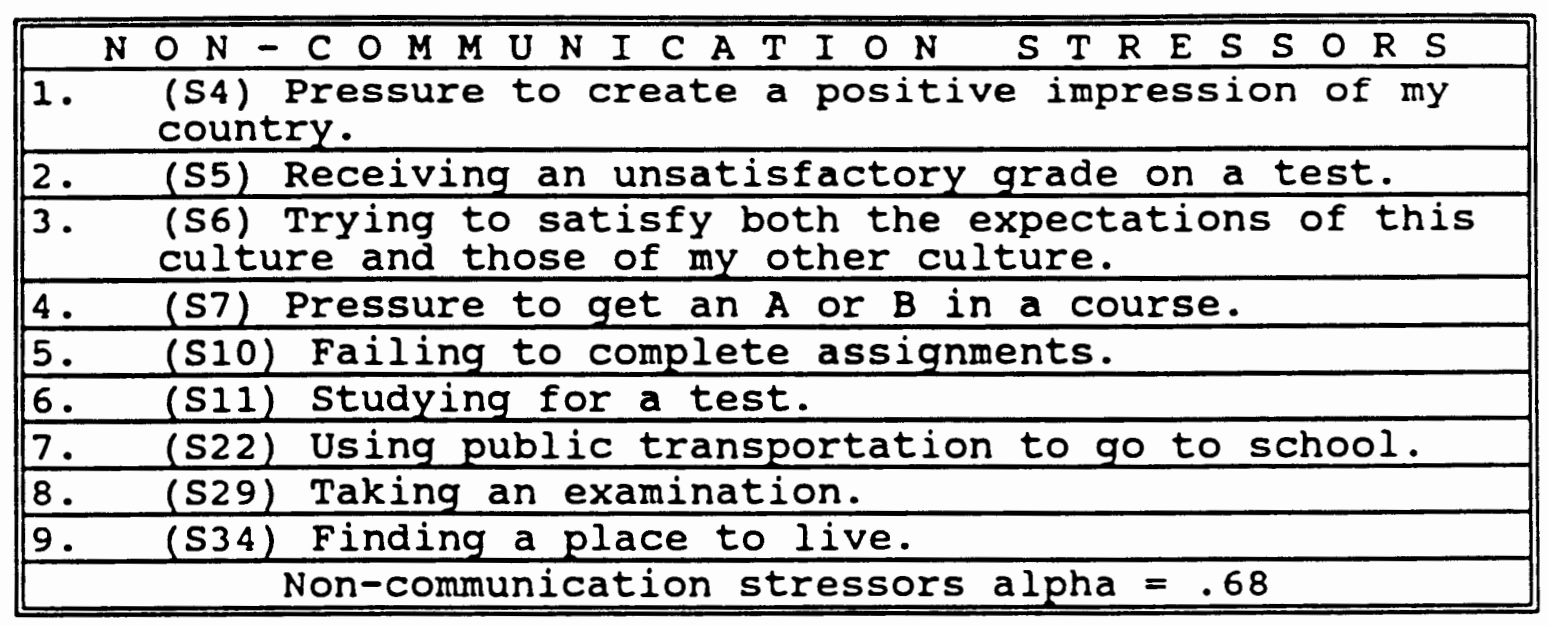

**Stressors 52 and 59 were taken out due to weak distributions.

\begin{tabular}{|c|c|}
\hline & $E M O T I O N-F O C U S E D$ \\
\hline 1. & (C2) Wait for things to get better. \\
\hline 2 . & (C3) Bargain or compromise. \\
\hline 3. & (C4) I do something which I don't think will work. \\
\hline 4. & (c6) Try to find out more about the situation \\
\hline 5. & (C7) Criticize or lecture myself. \\
\hline 6. & (c8) Try to keep my options open. \\
\hline 7. & (c9) Hope a miracle will happen. \\
\hline 8. & (C10) Accept my fate. \\
\hline 9. & (C11) I try to keep my feelings to myself. \\
\hline 10. & (c12) Try to look on the bright side of things. \\
\hline 11. & (C13) sleep more than usual. \\
\hline & $\begin{array}{l}\text { (C14) I express anger to the person(s) who caused the } \\
\text { problem. }\end{array}$ \\
\hline 13 . & $\begin{array}{l}\text { (C15) I tell myself things that help me to feel } \\
\text { better. }\end{array}$ \\
\hline 14 & $\begin{array}{l}\text { (C17) I wait to see what will happen before doing } \\
\text { anything. }\end{array}$ \\
\hline 15. & (C18) I apologize or do something to make up. \\
\hline 16. & (c20) I find a way to express my feelings. \\
\hline & (C21) Realize I brought the problem on myself. \\
\hline 18. & (C22) Talk to someone who can help solve the problem. \\
\hline 19. & (c23) Take a big chance or do something very risky. \\
\hline 20. & (C25) Maintain my pride. \\
\hline & (C27) Avoid being with people in general. \\
\hline & $\begin{array}{l}\text { (C28) I ask a relative or friend I respect for } \\
\text { advice. }\end{array}$ \\
\hline 23. & (C29) Keep others from knowing how bad things are. \\
\hline & (c30) Refuse to take the situation too seriously. \\
\hline & (C31) Talk to someone about how I am feeling. \\
\hline
\end{tabular}




\begin{tabular}{|c|c|}
\hline 26. & $\begin{array}{l}\text { E M O T I O N }-F O C U S E N D \text { O O P I N G } \\
\text { (C34) Promise myself things will be different next } \\
\text { time }\end{array}$ \\
\hline 27. & C35) Accept it, since nothing can be done. \\
\hline 28 . & $\begin{array}{l}\text { (C36) I try to keep my feelings from interfering with } \\
\text { other things. }\end{array}$ \\
\hline 29. & $\begin{array}{l}\text { (C37) Wish that I can change what happened or how I } \\
\text { feel. }\end{array}$ \\
\hline 30 . & $\begin{array}{l}\text { (C38) I imagine a better time or place than the one } \\
\text { I'm in. }\end{array}$ \\
\hline 31. & (c39) wish the situation didn't exist. \\
\hline 32. & c40) I pray about the situation. \\
\hline 33. & (C41) I prepare myself for the worst. \\
\hline 34. & (c44) I remind myself how much worse things could be. \\
\hline 35. & (C45) I jog, work out, or exercise. \\
\hline 36. & (C46) I ask for advice from a sheikh. \\
\hline & Emotion-focused coping alpha $=.84$ \\
\hline
\end{tabular}

\begin{tabular}{|c|c|}
\hline & $P$ R O B L L E M \\
\hline 1. & (CI) I try to analyze the problem. \\
\hline 2. & $\begin{array}{l}\text { (C5) Try to get the person responsible to change his } \\
\text { or her mind. }\end{array}$ \\
\hline 3. & (C16) Change my way of doing things. \\
\hline 4. & (C19) I make a plan of action and follow it. \\
\hline 5. & (C24) I try not to act too hastily. \\
\hline 6 . & $\begin{array}{l}\text { (C26) Change something so things will turn out all } \\
\text { right. }\end{array}$ \\
\hline 7. & (C32) stand my ground and fight for what I want. \\
\hline 8 . & $\begin{array}{l}\text { (C33) Draw on my past experiences to determine what } \\
\text { to do. }\end{array}$ \\
\hline 9. & (C42) Practice in my mind what I will say or do. \\
\hline 10. & (C43) I try to see the other person's point of view. \\
\hline & Problem-focused coping alpha $=.73$ \\
\hline
\end{tabular}


APPENDIX B

QUESTIONNAIRE 
QUESTIONNAIRE

ID\#

BIODEMOGRAPHICS-EXCEPT WHERE NOTED PLEASE WRITE THE NUMBER OF YOUR ANSWER TO THE RIGHT OF EACH ITEM.

1. How old are you?

2. What is your sex?

$1=$ Male $2=$ Female

3. What country are you from?

4. What is your current academic standing?

$1=$ Freshman $\quad 3=$ Junior $\quad 5=$ Graduate student

$2=$ Sophomore $4=$ Senior

5. What do you think your current G.P.A. is?

6. How long have you been in the U.S.? years months

7. Did you have any intercultural training

for this trip/sojourn before you left

your home country? $1=$ No $2=$ Yes

8. If so, how effective do you feel it was?

$0=$ doesn't apply

$1=$ not effective at all

$2=$ somewhat effective

$3=$ very effective

9. What type of program did you come on to

study in the U.S.?

$1=$ no program-independently

2 = government scholarship

$3=$ university exchange

$4=$ other

10. How long do you plan to Iive in the U.S.?

$1=$ less than 6 months

$2=6$ months to 1 year

$3=$ from $1-3$ years

$4=$ from $3-5$ years

$5=$ indefinitely

11. How actively do you practice the rituals of Islam?

$1=$ not at all

$2=$ somewhat

$3=$ completely 
SATISFACTION SCALE

PLEASE RANK THE FOLLOWING QUESTIONS ACCORDING TO THE SCALE OF :

Not at all (0); A little (1); Somewhat (2); A lot (3);

Completely (4)

1. How happy are you living in the U.S.?

2. If given the chance, how much would you like to remain

in the U.S. permanently?

3. How strongly would you recommend a close friend or relative from your native country come to study here?

\section{Stressors}

The following items indicate situations that may be stressful for you. If you have not had an event happen to you, please leave the item blank. For all of the events you have experienced, please report how often the experience is stressful according to the following scale:

Never (0); Rarely (1); Sometimes (2); Frequently (3); and Always (4).

1. Asking a question in class.

2. Acting as if $I$ am from the U.S. to gain acceptance.

3. Giving a class presentation.

4. Pressure to create a positive impression of my country.

5. Receiving an unsatisfactory grade on a test.

6. Trying to satisfy both the expectations of this culture and those of my other culture.

7. Pressure to get an $A$ or $B$ in a course.

8. Peer pressure to take part in social activities.

9. Cheating on a test.

10. Failing to complete assignments. 
Never (0); Rarely (1); Sometimes (2); Frequently (3); and Always (4).

11. Studying for a test.

12. Disagreements with instructor(s).

13. Personal contact with the faculty.

14. Speaking English.

15. Living among strangers for the first time.

16. Standing up for my own beliefs.

17. Being called on in class.

18. Making an appointment to meet a professor.

19. Knowing when it is appropriate to make a comment in class.

20. Registering for classes.

21. Asking so:ueone $I$ do not know to go to a social activity.

22. Using public transportation to go to school.

23. Asking non-Arab students to explain class material.

24. Asking Arab students to explain class material.

25. Discussing cultural problems with non-Arab students.

26. Discussing cultural problems with Arab students.

27. Discussing personal life problems with non-Arab students.

28. Discussing personal life problems with Arab students.

29. Taking an examination.

30. Socializing with individuals from the opposite sex.

31. Asking someone out on a date. 
Never (0); Rarely (1); Sometimes (2); Frequently (3); and Always (4).

32. Having an intimate relationship.

33. Responding to negative remarks about my culture.

34. Finding a place to live.

35. Asking for career/professional advice from faculty and school staff.

36. Dealing with roommate problems.

37. Getting needed health care.

\section{coping strategies}

When you experience a stressful situation in the U.S., how often do you use the following ways of coping?

Never (0); Rarely (1); Sometimes (2); Frequently (3); and Always (4).

1. I try to analyze the problem.

2. Wait for things to get better.

3. Bargain or compromise.

4. I do something which I don't think will work.

5. Try to get the person responsible to change his or her mind.

6. Try to find out more about the situation.

7. Criticize or lecture myself.

8. Try to keep my options open.

9. Hope a miracle will happen.

10. Accept my fate.

11. I try to keep my feelings to myself.

12. Try to look on the bright side of things.

13. Sleep more than usual. 
Never (0); Rarely (1); Sometimes (2); Frequently (3); and Always (4).

14. I express anger to the person(s) who caused the problem.

15. I tell myself things that help me to feel better.

16. Change my way of doing things.

17. I wait to see what will happen before doing anythin.

18. I apologize or do something to make up.

19. I make a plan of action and follow it.

20. I find a way to express my feelings.

21. Realize I brought the problem on myself.

22. Talk to someone who can help solve the problem.

23. Take a big chance or do something very risky.

24. I try not to act too hastily.

25. Maintain my pride.

26. Change something so things will turn out all right.

27. Avoid being with people in general.

28. I ask a relative or friend I respect for advice.

29. Keep others from knowing how bad things are.

30. Refuse to take the situation too seriously.

31. Talk to someone about how I am feeling.

32. Stand my ground and fight for what I want.

33. Draw on my past experiences to determine what to do.

34. Promise myself things will be different next time.

35. Accept it, since nothing can be done. 
Never (0); Rarely (1); Sometimes, (2); Frequently (3); and Always (4).

36. I try to keep my feelings from interfering with other things.

37. Wish that I can change what happened or how I feel.

38. I imagine a better time or place than the one I'm in.

39. Wish the situation didn't exist.

40. I pray about the situation.

41. I prepare myself for the worst.

42. Practice in my mind what I will say or do.

43. I try to see the other person's point of view.

44. I remind myself how much worse things could be.

45. I jog, work out, or exercise.

46. I ask for advice from a sheikh.

THANK YOU VERY MUCH FOR YOUR COOPERATION 
APPENDIX C

PILLARS OF ISLAMIC FAITH 


\section{PILLARS OF ISLAMIC FAITH}

In order to effectively illustrate the effect of Islam, included is an explanation by Almaney and Alwan (1982) of the 5 (or 6) basic pillars of Islam, and the growth of Islam into a fully conceptualized way of living which affects the lives and communication among Muslims today (see also Hamidullah, 1980; Hawting, 1987; Khalidi, 1975; Sauders, 1965; Smith, 1957). The period of pre-Islam is referred to by Arabs as Al-Jahiliya. It means 'age of ignorance'. This is in reference to the fact that these peoples had no designated prophet or religious doctrine. These lifestyles, mythic and religious traditions experienced a dramatic change upon the arrival of one man named Muhammed.

During adulthood, Muhammed spent much of his time in contemplation in a cave on Mount Hira. During his stays on Mount Hira, Muhammed experienced supernatural visitations from Gabriel, Allah's messenger. The initial message which led to the beginning of Muhammed's preaching of Islam went as follows:

\section{Recite in the name of thy Lord who created, Created man from a clot. \\ Recite! For thy Lord is most gracious, Who taught with the pen, Taught man what he knows not.}

H. Al-lawati (personal communication, May 14, 1991)

Muhammed received many other messages that instructed him to start preaching the word of Islam. What began with small secretive meetings with members of his family, soon 
spread to others. The believers of Islam became more public in their proclamations of Muhammed as God's prophet and Islam as the one true faith. Most Meccans were not concerned with the uprising of Islam until they "realized that Muhammed was not a harmless crank but a dangerous revolutionary. He was calling their religion a fraud, their priests charlatans, their gods false, and their time-honored traditions worthless" (Almaney \& Alwan, 1982, p. 37). Muhammed sought safe refuge with some of the most powerful members of his own tribe, but when they died, he had to flee for his life. He left Mecca and traveled to Medina. This flight is called the Hijra and proved to be the greatest influence on the spread of Islam. A group of pilgrims observed Muhammed preaching on the way to Medina and thought he was the prophet the Jews were waiting for. These pilgrims immediately converted to Islam and the growth of the religion dramatically increased. The security and acceptance Muhammed experienced in Medina led him to taking on political, military and social leadership roles. The function of Muhammed in these roles are important for they led to the doctrine of Islam being applied to all aspects of the Muslim life.

\section{Islam and the five pillars}

Islam is defined as submission to the will of Allah (God). It is the giving of oneself completely to the belief in Him. Islam covers social, political, religious, and 
individual concerns. It provides the answers to the questions that a group of humans may formulate when placed together. Islam is a way of life: a culture. There is no aspect of life that can be separated from the belief system of Islam.

The system that Muhammed established did not recognize separate spheres for "church" and "state". Rather, the two are so meshed together in classical Islam that it is impossible to talk about one in isolation from the other. The Islamic community created by Muhammed was at once a religious brotherhood, a political association, and a social order (Almaney \& Alwan, 1982, p. 43).

The previous brief explanation provides an overview of what Islam had to offer its believers. In order to follow the way of Islam and achieve spiritual unity with Allah, a Muslim was and is advised to practice the five pillars of Islam.

\section{Pillar I: Profession of the Faith (Al-Shihadah)}

The first step in becoming a Muslim is an open profession of faith. This is a declaration that Allah is the one true God and that no other gods will be worshipped. It is what is referred to as the submission to Allah, or the giving of oneself to the belief in only Him. It also includes declaring that Muhammed is the messenger of Allah. Muslims chant this message five times a day during prayer.

\section{Pillar II: Prayer (Al-Salah)}

Muslims pray five times a day between sun up and sunset. A mosque is the ideal place to partake in prayer, 
but one may pray wherever he or she is. The prayer ritual includes bowing, kneeling and chanting. one must be pure to pray, so Muslims wash their hands, face, and feet before praying. Often Muslims will also face Mecca no matter where they are in the world.

\section{Pillar III: Almsgiving (Al-Zakat)}

Muslims give 2.5 percent of their gross earnings to the poor. Muhammed originated this levy in order to supply money for the poor and to defer government costs. This self-imposed levy is regarded as an act of piety and love.

\section{Pillar IV: Fasting (Al-Sawm)}

Ramadan is the thirty day lunar month that Muslims do not partake of eating, smoking, drinking, or having sexual intercourse during the hours from sun up to sunset. It functions as a purification of the body, mind and soul in order to rededicate oneself to Allah.

\section{Pillar V: Pilgrimage (Al-Haj)}

All able-bodied Muslims are required to make a pilgrimage to Mecca once in their lifetime. This ritual is a unifying force that draws rich and poor together without the boundaries placed on them in society. Everyone dresses in plain clothes and ventures to the Kaaba at Mecca. The Kaaba houses the meteoric Black stone upon which Abraham was to have sacrificed his son, Issac. Many rituals are performed there by the whole gathering of Muslims. Non- 
Muslims are not allowed to go to Mecca.

Pillar VI: Holy War (Al-Jihad)

Some consider participating in a holy war of Muslims against non-Muslims to be the sixth pillar of Islam. AlJihad carries with it the promise of salvation. In reality, Al-Jihad simply means to spread the message of Islam. This, needless to say, can be done without a holy war. 